\title{
Exploring the decomposition pathways of iron asymmetric transfer hydrogenation catalysts
}

\author{
Paraskevi O. Lagaditis, Peter E. Sues, Alan J. Lougha \\ and Robert H. Morris
}

\author{
Version Post-print/accepted manuscript \\ Citation Lagaditis, P. O., Sues, P. E., Lough, A. J., \& Morris, R. H. (2015). \\ (published version) Exploring the decomposition pathways of iron asymmetric transfer \\ hydrogenation catalysts. Dalton Transactions, 44(27), 12119-12127.
}

Publisher's statement The final published version of this article is available from the Royal Society of Chemistry at http://dx.doi.org/10.1039/C4DT02799J.

How to cite TSpace items

Always cite the published version, so the author(s) will receive recognition through services that track citation counts, e.g. Scopus. If you need to cite the page number of the author manuscript from TSpace because you cannot access the published version, then cite the TSpace version in addition to the published version using the permanent URI (handle) found on the record page.

This article was made openly accessible by $U$ of T Faculty. Please tell us how this access benefits you. Your story matters. 


\title{
Exploring the Decomposition Pathways of Iron Asymmetric Transfer Hydrogenation Catalysts
}

\author{
Paraskevi O. Lagaditis ${ }^{a}$, Peter E. Sues ${ }^{a}$, Alan J. Lough ${ }^{a}$, and Robert H. Morris ${ }^{a *}$ \\ Our group has developed a series of iron-based asymmetric transfer hydrogenation (ATH) catalysts for the reduction of polar \\ double bonds. The activation of the precatalysts as well as the catalytic mechanism have been thoroughly investigated, but the \\ decomposition pathways of these systems are poorly understood. Herein, we report a study of the deactivation pathways for an \\ iron ATH catalyst under catalytically relevant conditions. The decomposition pathways were examined using experimental \\ techniques and density functional theory (DFT) calculations. The major decomposition products that formed, \\ $\mathrm{Fe}(\mathrm{CO})\left((\mathrm{Et})_{2} \mathrm{PCH}_{2} \mathrm{CH}_{2} \mathrm{CHCHNCH}_{2} \mathrm{CH}_{2} \mathrm{P}(\mathrm{Et})_{2}\right)(3 \mathbf{3})$ and $\left.\mathrm{Fe}(\mathrm{CO})\left((\mathrm{Et})_{2} \mathrm{PCH}_{2} \mathrm{CH}_{2} \mathrm{C}(\mathrm{Ph}) \mathrm{C}(\mathrm{Ph}) \mathrm{NCH}_{2} \mathrm{CH}_{2} \mathrm{P}(\mathrm{Et})\right)_{2}\right)(3 \mathbf{b})$, had two \\ amido donors as well as a $\mathrm{C}=\mathrm{C}$ bond on the diamine backbone of the tetradentate ligand. These species were identified by NMR \\ studies and one was isolated as a bimetallic complex with $\mathrm{Ru}(\mathrm{II}) \mathrm{Cp}$ * Two minor iron hydride species also formed concurrently \\ with 3a, as determined by NMR studies, one of which was isolated and contained a fully saturated ligand as well as a hydride \\ ligand. None of the compounds that were isolated were found to be active ATH catalysts.
}

${ }^{a}$ Department of Chemistry, University of Toronto, Toronto, Ontario, M5S 3H6, Canada.

*E-mail:rmorris@chem.utoronto.ca

\section{Introduction}

Iron is an attractive metal for industrial catalytic applications, not only because of its lower cost, but also for its lower toxicity relative to the platinum group metals. $^{1,2}$ In addition, iron is the most abundant transition metal found in earth's crust; thus catalysts based on iron are significantly more sustainable than those reliant on trace metals. ${ }^{3-6}$ A well-known use of iron in industry is as a heterogeneous catalyst for the production of ammonia via the Haber-Bosch process. ${ }^{7}$ Unfortunately, the progress of homogeneous iron catalysis has not had the same type of success, unlike the platinum group metals., 4 Iron has often been overlooked partly because it does not readily engage in two electron reactions, thereby precluding it from many catalytic reactions that depend on oxidative additions or reductive eliminations. ${ }^{8}$ Instead, iron engages in one electron processes $\left(\mathrm{Fe}^{\mathrm{II}} / \mathrm{Fe}^{\mathrm{III}}\right)$ which can lead to radical reactions and increase the propensity for unselective and uncontrollable side reactions. ${ }^{8}$ The careful design of ligands suitable for iron, or other first-row transition metals, however, can circumvent this pitfall. In particular, multi-dentate ligands that promote metalligand cooperativity, as well as a strong field ligand such as a CO ligand, that stabilizes low spin electronic structures, have been shown to be paramount in creating active iron catalysts. ${ }^{9-17}$ As a result of this understanding of the ligand requirements, the emergence of iron complexes to replace catalysts based on $\mathrm{Ru}$, Ir or $\mathrm{Rh}$ is becoming more of a reality. ${ }^{4}$

Recently, the Morris group has reported several generations of iron asymmetric transfer hydrogenation
(ATH) catalysts bearing tetradentate P-N-N-P ligands. ${ }^{18-22}$ Various substitutions with respect to the ligand backbone, ${ }^{23}, 24$ as well as the phosphorus donors ${ }^{25,} 26$ have been carried out, along with extensive kinetic, ${ }^{27}$ mechanistic, ${ }^{28,}{ }^{29}$ and computational studies ${ }^{30}$, 31 to elucidate the mechanism of catalysis. One of the key discoveries in this area was the isolation and characterization of bis-eneamido intermediates that form upon the treatment of the second-generation catalysts (second-generation refers to iron carbonyl ATH precatalysts with two imine donors, and a methylene linker between the imine and phosphorus moieties) with base (Figure 1). ${ }^{28}$ The bis-eneamido species were not active catalysts themselves, but gave a well-defined entry point into the activation process, which lead to catalytically active species. ${ }^{30}$ Understanding the activation process, in turn, lead to the development of a more active third-generation of catalysts, where one of the imine donors has been reduced to an amino group. ${ }^{22,32}$ These third-generation catalysts have the same catalytic intermediates as the second generation catalysts, but enter the catalytic cycle much more readily. ${ }^{22,27}$ 

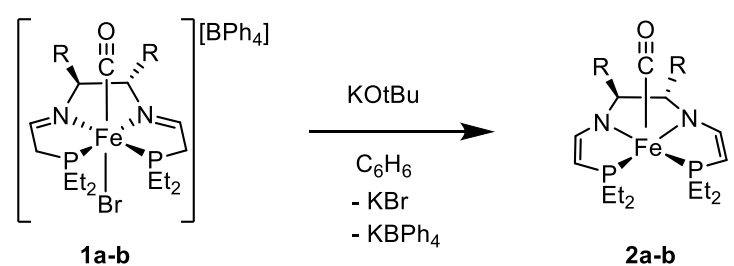

Figure 1. Generation of bis-eneamido species $\mathbf{2} \mathbf{a}-\mathbf{b}$ from the secondgeneration precatalysts $\mathbf{1} \mathbf{a}-\mathbf{b}$.

Although the activation of the second-generation precatalysts is well understood, as is the catalytic mechanism of ketone hydrogenation, the deactivation pathways for the catalytic intermediates are not fully known. Knowledge of decomposition pathways is critical for catalyst development because it allows for modifications of the catalyst structure, which increase the lifetime of the catalytic system. In doing so, the total number of turnovers that the catalyst can achieve, or the turnover number (TON), increases while the turnover frequency (TOF) may or may not be affected. The TON is an important metric for the chemical industry, where an extremely active catalyst with poor TON is often less desirable than a less active catalyst that can produce more product, or even potentially be reused for multiple applications. ${ }^{33-35}$ Herein, we report several unexpected deactivation pathways observed for complexes $\mathbf{1 a - b}$ and 2a-b under catalytic conditions. These decomposition pathways were examined using experimental techniques and density functional theory (DFT) calculations.

\section{Results and Discussion}

Synthesis of decomposition products $3 \mathbf{a}$ and $3 \mathbf{b}$. After a standard ATH reaction such as the asymmetric reduction of acetophenone by transfer of hydrogen from isopropanol catalysed by $\mathbf{1 a - b}$ or $\mathbf{2 a - b}$ had proceeded to the final equilibrium solution with product alcohol and acetone, the solution often turned a deep red colour. In addition, iron precatalysts with phosphorus donors bearing ethyl substituents were found to rapidly deactivate during catalysis when compared to the complexes with aryl groups on the phosphine functionalities. ${ }^{32}$ This was apparent from the fact that the addition of further equivalents of catalyst were needed to drive the reaction to equilibrium for the ethylsubstituted systems. By contrast, the catalysts bearing aryl groups continued to be active when additional substrate was added to the reaction mixture after the first reaction had reached equilibrium. ${ }^{32}$ The ethylsubstituted iron complexes were therefore chosen to probe catalyst decomposition pathways in an effort to help identify future catalyst modifications that would produce more robust systems.
Using iron(II) precatalysts $\mathbf{1 a}$ and $\mathbf{1 b}$, as well as biseneamido complexes $\mathbf{2 a}$ and $\mathbf{2 b}$ as convenient starting points, two approaches were used to determine what $\mathbf{a}=\mathrm{H} \quad$ species form from iPrOH after base activation. The first $\mathbf{b}=\mathrm{Ph}$ method involved the dissolution of the isolated iron biseneamido complexes in isopropanol (Figure 2, Method A), while the second method focused on the deprotonation of the $[\mathrm{Fe}(\mathrm{CO})(\mathrm{Br})(\mathrm{P}-\mathrm{N}-\mathrm{N}-\mathrm{P})]\left[\mathrm{BPh}_{4}\right]$ complexes with $\mathrm{NaOiPr}$, thereby generating $\mathrm{iPrOH}$ in situ (Figure 2, Method B). When either method was used, starting from complexes $\mathbf{1 a - b}$ or $\mathbf{2 a - b}$, the colour of the solution would initially discolour and eventually the reaction mixture turned red in colour. NMR spectroscopy of the isolated red residues revealed a new major compound was formed as well as several other minor species.

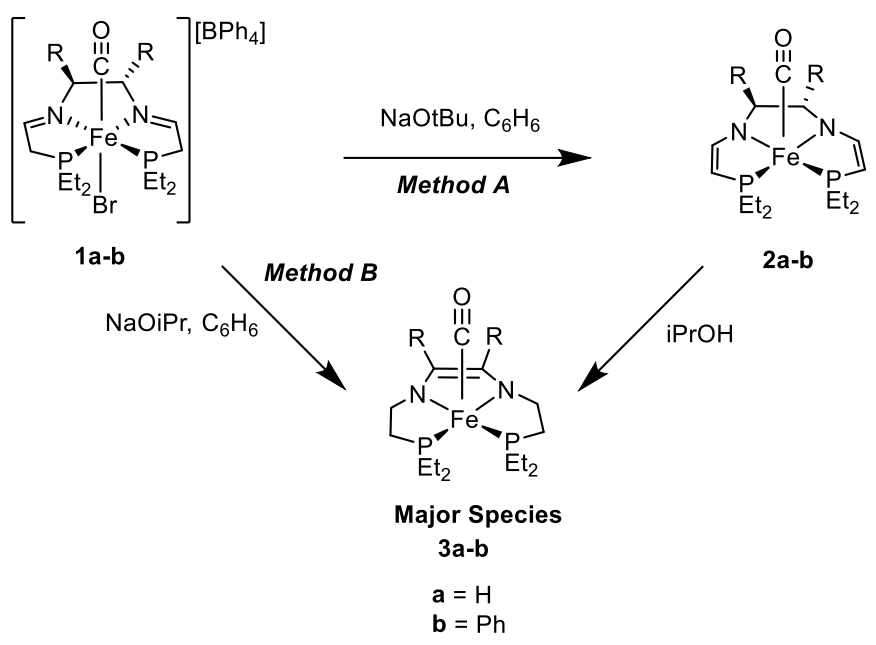

Figure 2. Synthesis of complexes $\mathbf{3 a}$ and $\mathbf{3 b}$ using Method A and Method B.

Characterization of 3a. Regardless of which method was applied for the ethylenediamine backbone variant, with $1 \mathbf{a}$ or $\mathbf{2 a}$ as the starting material, the reaction mixture turned red within $2-4 \mathrm{~h}$. The ${ }^{31} \mathrm{P}\left\{{ }^{1} \mathrm{H}\right\}$ NMR spectrum of the reaction mixture revealed a major compound with a singlet resonance at $84.1 \mathrm{ppm}$ and minor compounds with doublet resonances. In addition, the ${ }^{1} \mathrm{H}$ NMR spectrum showed that saturation of the ligand P-N-linker had occurred and that the ethane N-Nlinker had lost two hydrogen atoms to become an ethene linker. Two hydrides with doublet of doublet resonances were also detected, but their intensity suggested that they did not correspond to the major compound (vide infra). Thus, the structural identification of the red compounds 3a was pursued starting from $1 \mathbf{1} / \mathbf{2 a}$ since they reacted relatively quickly with $\mathrm{NaOiPr}$ or $\mathrm{iPrOH}$, respectively. 
The crude red residue of $\mathbf{3 a}$ was taken up in pentane and filtered to afford a pure compound with no hydride signals, as determined by ${ }^{1} \mathrm{H}$ NMR spectroscopy. The ${ }^{11} \mathrm{~B}$ NMR spectrum of the crude product showed that $\mathrm{BPh}_{4}^{-}$was present when Method B was applied as shown in Figure 2, but then disappeared after purification, implying that 3a was a neutral compound. The $\mathrm{BPh}_{4}^{-}$resonances, as expected, could be found in the remaining precipitate when dissolved in THF- $d_{8}$ (vide infra). In addition, the IR spectrum of $\mathbf{3 a}$ showed a $v_{\mathrm{CO}}$ resonance at $1850 \mathrm{~cm}^{-1}$ demonstrating that the $\mathrm{CO}$ ligand was still bound to the metal centre. Similar to $\mathbf{2 a}$, we postulated that $\mathbf{3 a}$ was a 5-coordinate iron(II) compound, but crystals suitable for X-ray diffraction, which were not forthcoming, are needed to unequivocally assign the structure.

One approach that was undertaken to infer the structure of $3 \mathbf{a}$ was to deuterate with $\mathrm{DCl}(1 \mathrm{M})$ in $\mathrm{Et}_{2} \mathrm{O}$ in the hope that it would allow the determination of the structure, as was done previously for compounds $\mathbf{2 a - b}{ }^{28}$ Upon addition of $\mathrm{DCl}$ (4 equiv.) to $\mathbf{3 a}$ in $\mathrm{Et}_{2} \mathrm{O}$, the homogeneous red solution turned into a yellow slurry immediately. The yellow solid was isolated and analyzed by ${ }^{31} \mathrm{P}$ and ${ }^{1} \mathrm{H}$ NMR spectroscopy in $\mathrm{CD}_{2} \mathrm{Cl}_{2}$. Unfortunately, the ${ }^{1} \mathrm{H}$ NMR spectrum was complex thus suggesting a mixture and the ${ }^{31} \mathrm{P}\left\{{ }^{1} \mathrm{H}\right\}$ NMR spectrum showed that there were three compounds with inequivalent phosphines at 72.6 and $78.6 \mathrm{ppm}\left({ }^{2} J_{\mathrm{PP}}=\right.$ $43.2 \mathrm{~Hz}), 65.3$ and $68.8\left({ }^{2} J_{\mathrm{PP}}=33.4 \mathrm{~Hz}\right)$ and 65.6 and $67.2 \mathrm{ppm}\left({ }^{2} J_{\mathrm{PP}}=34.5 \mathrm{~Hz}\right)$. Based on the phosphorus coupling constants, the phosphorus atoms are cis about the iron centre. When this mixture of compounds was reacted with an excess of base $(\mathrm{NaOtBu})$ in a THF/benzene solution, the reaction turned red immediately and reformed compound 3a quantitatively, as determined by NMR spectroscopy. Crystals of one of the diastereomers were obtained from the slow evaporation of a solution of $\mathrm{CD}_{2} \mathrm{Cl}_{2}$ in an NMR tube at room temperature. This compound, $\mathbf{4}$, contains a ligand that is partially reduced by isopropanol (Figure 3). Both $\mathrm{P}-\mathrm{N}$ ligand arms are fully saturated and the imine double bond has migrated to the diamine backbone. The N(1) and $\mathrm{C}(1)$ may have been deuterated, but this cannot be verified by X-ray crystallography nor confirmed definitively by NMR spectroscopy. In addition, $\mathbf{4}$ is a cationic iron complex with a $\mathrm{Cl}^{-}$ligand coordinated trans to the $\mathrm{CO}$ ligand, which implies that $\mathbf{3 a}$ is a neutral five-coordinate iron complex. Figure 4 shows a possible mechanism of formation of 4 . For the other two diastereomers, on the other hand, one could have a $\mathrm{CO}$ ligand trans to the $\mathrm{N}$-imine moiety, while the other isomer could have a CO ligand trans to a phosphorus atom. Nonetheless, compound $\mathbf{4}$ shows good evidence to support the proposal that the diamine backbone has been dehydrogenated.

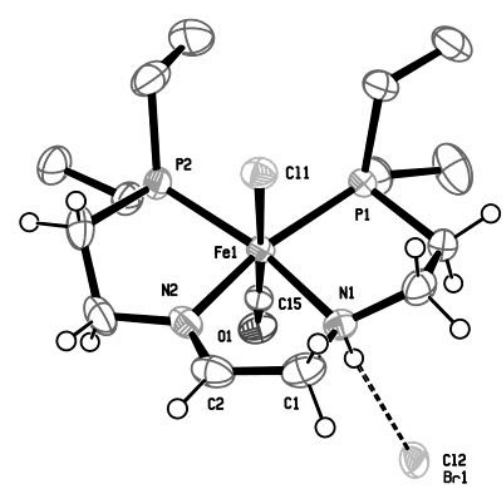

Figure 3. ORTEP plot (thermal ellipsoids at $50 \%$ probability) of 4 . Et hydrogen atoms removed for clarity. Selected bond lengths ( $\AA$ ) and angles (deg): $\mathrm{Fe}(1)-\mathrm{C}(15): 1.742(3) ; \mathrm{Fe}(1)-\mathrm{Cl}(1)$ : 2.3880(8); $\mathrm{N}(1)-\mathrm{C}(1)$ : 1.487(4); N(2)-C(2): 1.273(5); O(1)-C(15): 1.133(4); $\mathrm{P}(2)-\mathrm{Fe}(1)-\mathrm{P}(1)$ : 106.99(3).

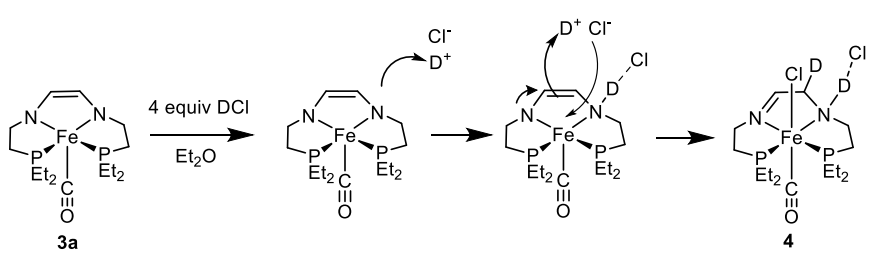

Figure 4. A possible mechanism for the formation of 4 through the deuteration of $3 a$ with DCl.

Another approach to confirm the structure of $\mathbf{3 a}$ took advantage of the aromaticity found between the metal and the ligand backbone. The - $(\mathrm{Fe}-\mathrm{N}-\mathrm{C}-\mathrm{C}-\mathrm{N})$ - ring of $\mathbf{3 a}$ has six electrons in a $\pi$ system, two on each $\mathrm{N}$ and two in the double bond, thus fulfilling the requirements for an aromatic ring. It can also be viewed as an $\mathrm{XL}_{2}$ ligand in the covalent bonding notation. Moreover, our group has shown that ruthenium hydrogenation catalysts with diamine ligands are prone to dehydrogenation of the ligand backbone, much like 3a, to form aromatic rings. ${ }^{36}$ The observation that a $\mathrm{Ru}(\mathrm{H})\left(\mathrm{PPh}_{3}\right)_{2}$ fragment coordinated in a $\kappa^{5}$ fashion to a $-(\mathrm{Ru}-\mathrm{N}-\mathrm{C}-\mathrm{C}-\mathrm{N})-$ chelate ring was consistent with this proposal. ${ }^{36}$ Fekl and coworkers have shown similar behaviour with their nickeldithiolene complexes where the -(Ni-S-C-C-S)- chelate ring coordinated a $\mathrm{Cp} * \mathrm{Fe}$ fragment. ${ }^{37} \mathrm{In}$ light of this we postulated that the $-(\mathrm{Fe}-\mathrm{N}-\mathrm{C}-\mathrm{C}-\mathrm{N})-$ ring of 3a would coordinate in an $\kappa^{5}$ fashion to an appropriate metal fragment to form a bimetallic complex. The $[\mathrm{Cp} * \mathrm{Ru}]^{+}$ fragment with its high affinity for arenes and heteroarenes works well. ${ }^{38}$

A THF solution of $\left[\mathrm{Cp} * \mathrm{Ru}\left(\mathrm{NCCH}_{3}\right)_{3}\right]\left[\mathrm{PF}_{6}\right]$ was therefore added to $\mathbf{3 a}$. The reaction mixture turned 
green-black immediately and a ${ }^{31} \mathrm{P}\left\{{ }^{1} \mathrm{H}\right\}$ NMR (THF- $d_{8}$ ) spectrum of the isolated solid residue displayed a new singlet at $76.5 \mathrm{ppm}$ for a new bimetallic Ru halfsandwich compound, $\mathbf{5}$, as well as a minor singlet at 72.4 ppm (Figure 5). The ${ }^{13} \mathrm{C}\left\{{ }^{1} \mathrm{H}\right\}$ NMR spectrum displayed only one triplet resonance for the CO ligand at 220.26 ppm $\left({ }^{2} J_{\mathrm{CP}}=24.2 \mathrm{~Hz}\right)$, and the IR $(\mathrm{KBr})$ spectrum displayed a major $v_{\mathrm{CO}}$ resonance at $1956 \mathrm{~cm}^{-1}$ along with a minor resonance at $1898 \mathrm{~cm}^{-1}$. Crystals suitable for Xray diffraction of $\mathbf{5}$ were grown from slow diffusion of pentane into THF- $d 8$ and confirmed our proposals of not only the $\kappa^{5}$ bonding of the ruthenium in $\mathbf{5}$, but also of the nature of the unsaturation in 3a (Figure 6). Compound 5 has only one $\mathrm{PF}_{6}{ }^{-}$anion, which implies that 3a was indeed a neutral compound. Unfortunately, the $\mathrm{X}$-ray structure is highly disordered, such that accurate bond lengths and bond angles cannot be reported. We attribute the disorder to the flexible nature of the saturated PN ligand arms. There is no disorder in the CO ligand, however, which is found on the same side as the RuCp* unit. This could be a result of crystal packing in the solid state. Nonetheless, the experiment gives strong evidence in support of our formulation of the structure of 3a (as well as its analog $\mathbf{3 b}$ ) first shown in Figure 2. The minor isomer of 5 detected by IR ( $v(C O) 1898 \mathrm{~cm}^{-}$ 1) may have the $\mathrm{CO}$ on the opposite side of the iron complex to that of the ruthenium.

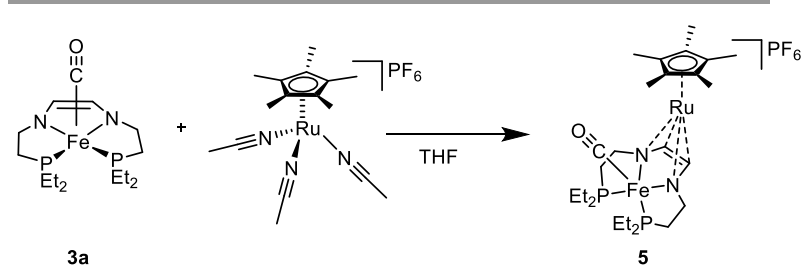

Figure 5. Synthesis of the half-sandwich bimetallic complex $\mathbf{5}$.

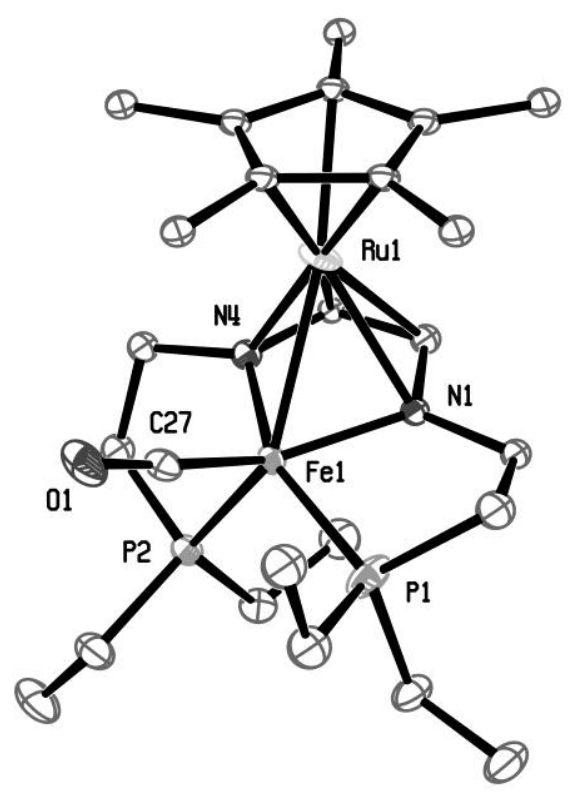

Figure 6. ORTEP plot (thermal ellipsoids at $30 \%$ probability) of compound 5. $\mathrm{PF}_{6}{ }^{-}$anion, hydrogen atoms and disorder removed for clarity.

Compound 3a was also tested for transfer hydrogenation of acetophenone at $50^{\circ} \mathrm{C}$ under the same conditions used with compound $2 \mathbf{a}(\mathrm{C} / \mathrm{S}: 1 / 200,6 \mathrm{~mL}$ $\mathrm{iPrOH})$ and found to be inactive. It was also tested with additional base ( 8 equiv. KOtBu) and still found to be inactive. Thus, compound $\mathbf{3 a}$ is a deactivated byproduct formed during catalysis.

Characterization of $\mathbf{3 b}$. The reaction at $25^{\circ} \mathrm{C}$ of base in benzene with $\mathbf{1 b}$ or $\mathbf{2 b}$ containing an $(S, S)-1,2-$ diphenylethylenediamine $((S, S)$-dpen) backbone was much slower as indicated by the loss of a green colour and the appearance of a red colour over the course of a three month period. This process could be accelerated, progressing to completion in 3 weeks, by adding 10 equiv. of $\mathrm{iPrOH}$ and 10 equiv. of acetone to the reaction mixture. Using iPrOH as the solvent also gave $\mathbf{3 b}$ in a much shorter time period, 5-6 hours, but with byproducts.

Significantly, while the starting compounds $\mathbf{1 b}$ and 2b have inequivalent ${ }^{31} \mathrm{P}$ nuclei in their tetradentate ligand, compound $\mathbf{3 b}$ has magnetically equivalent nuclei that produce a singlet resonance in the ${ }^{31} \mathrm{P}$ NMR spectrum at $82.1 \mathrm{ppm}$. A singlet resonance supports a loss of chirality in the $\mathrm{N}-\mathrm{N}$ diamine backbone and reinforces the notion that the dehydrogenation of the diamine had occurred. In addition, the disappearance of the $(S, S)$-dpen methylene protons in the ${ }^{1} \mathrm{H}$ NMR spectrum also supported that this reaction had taken place.

In order to show the relevance of these decomposition products to catalysis, an NMR 
investigation of an ATH reaction was also carried out. Complex 2b was dissolved in benzene- $d_{6}$, followed by the addition of 2 equiv. of iPrOH and 2 equiv. of acetophenone. Benzene was chosen as the solvent because previous unreported tests have found that the transfer hydrogenation reaction with our iron(II) complexes slows down significantly in this solvent. We attribute this lower activity to the lower dielectric constant of benzene $(\varepsilon=4.26)$ as compared to $\mathrm{PrOH}$ ( $\varepsilon$ $=20.18$ ), in addition to the lower concentration of iPrOH. ${ }^{39}$ It was hoped that the benzene- $d 6$ solvent would slow down the ATH reaction enough to allow observation of the formation of any interesting intermediates via ${ }^{31} \mathrm{P}\left\{{ }^{1} \mathrm{H}\right\} \quad$ NMR spectroscopy. Furthermore, with benzene- $d_{6}$ as the solvent, the reaction progress could be monitored via ${ }^{1} \mathrm{H}$ NMR spectroscopy through the formation of acetone and 1phenylethanol. Figure 7 shows the ${ }^{31} \mathrm{P}\left\{{ }^{1} \mathrm{H}\right\}$ NMR spectra of the reaction progress over two weeks. The ${ }^{31} \mathrm{P}\left\{{ }^{1} \mathrm{H}\right\}$ NMR spectra obtained at $50{ }^{\circ} \mathrm{C}$ after $30 \mathrm{~min}$ of mixing appeared to show no reaction had occurred because the spectrum mainly displayed phosphorus resonances of $\mathbf{2 b}$ (major and minor compounds as described previously). ${ }^{28}$ On the other hand, the ${ }^{1} \mathrm{H}$ NMR spectrum showed the formation of acetone and 1phenylethanol (30\% conversion based on the integration of the $-\mathrm{CH}_{3}$ proton resonances relative to acetophenone). Hence, catalytic species had formed from the reaction of $\mathbf{2} \mathbf{b}$ with iPrOH, but they were either paramagnetic or their concentration was too small to detect in the ${ }^{31} \mathrm{P}\left\{{ }^{1} \mathrm{H}\right\}$ NMR spectrum. The reaction was then allowed to sit in the glove box for one week. During this time the formerly green solution had turned very dark in colour, almost black. The ${ }^{31} \mathrm{P}\left\{{ }^{1} \mathrm{H}\right\}$ NMR spectrum now showed the appearance of a sharp singlet at $82.1 \mathrm{ppm}$, the two doublets of the minor compound from the starting material $\mathbf{2 b}$ (68.3 and $77.1 \mathrm{ppm})$ and the disappearance of the broad signal of $\mathbf{2 b}$ itself (67.7 ppm). The ${ }^{1} \mathrm{H}$ NMR spectrum showed only acetone and $80 \%$ conversion of acetophenone to 1-phenethanol, while the resonance of the singlet in the ${ }^{31} \mathrm{P}\left\{{ }^{1} \mathrm{H}\right\}$ NMR spectrum matched the singlet of $\mathbf{3 b}$. After sitting in the glove box for an additional week the solution became bright red in colour and the ${ }^{31} \mathrm{P}\left\{{ }^{1} \mathrm{H}\right\}$ NMR spectrum only displayed the sharp singlet at $82.1 \mathrm{ppm}$. Thus, the formation of compound $\mathbf{3 b}$ was found to be relevant under catalytic conditions.

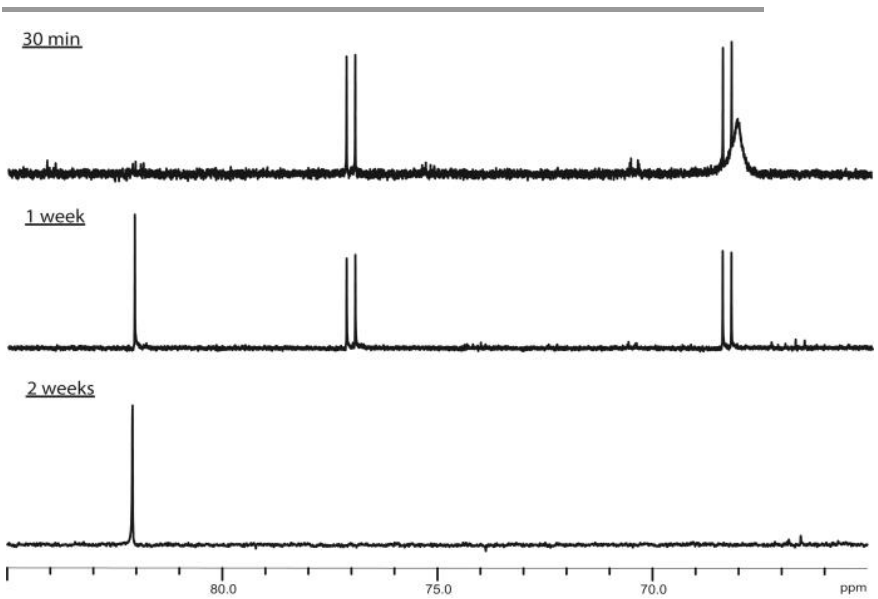

Figure 7. ${ }^{31} \mathrm{P}\left\{{ }^{1} \mathrm{H}\right\}$ NMR spectra of the formation of $\mathbf{3 b}$ under catalytically relevant conditions.

Proposed mechanism of formation for $\mathbf{3 a - b}$ supported by DFT calculations. Since compounds 3ab were only formed in the presence of $\mathrm{iPrOH}$ and never observed to form from a tertiary alcohol (HOtBu), ligand reduction was considered to be a likely first step in generating the decomposition products. Using a slightly simplified version of the bis-eneamido complex 2a as our starting point, $\mathbf{A}$ (the ethyl substituents on the phosphorus donors were replaced with methyl groups to reduce computational costs), a possible mechanism of formation for $\mathbf{3} \mathbf{a}$, and by extension $\mathbf{3} \mathbf{b}$, was explored computationally with DFT. Our study was based on the initial presence of $\mathbf{A}$, as well as two molecules of $\mathrm{iPrOH}$ (all other energies were compared to these species, Figure 8). 

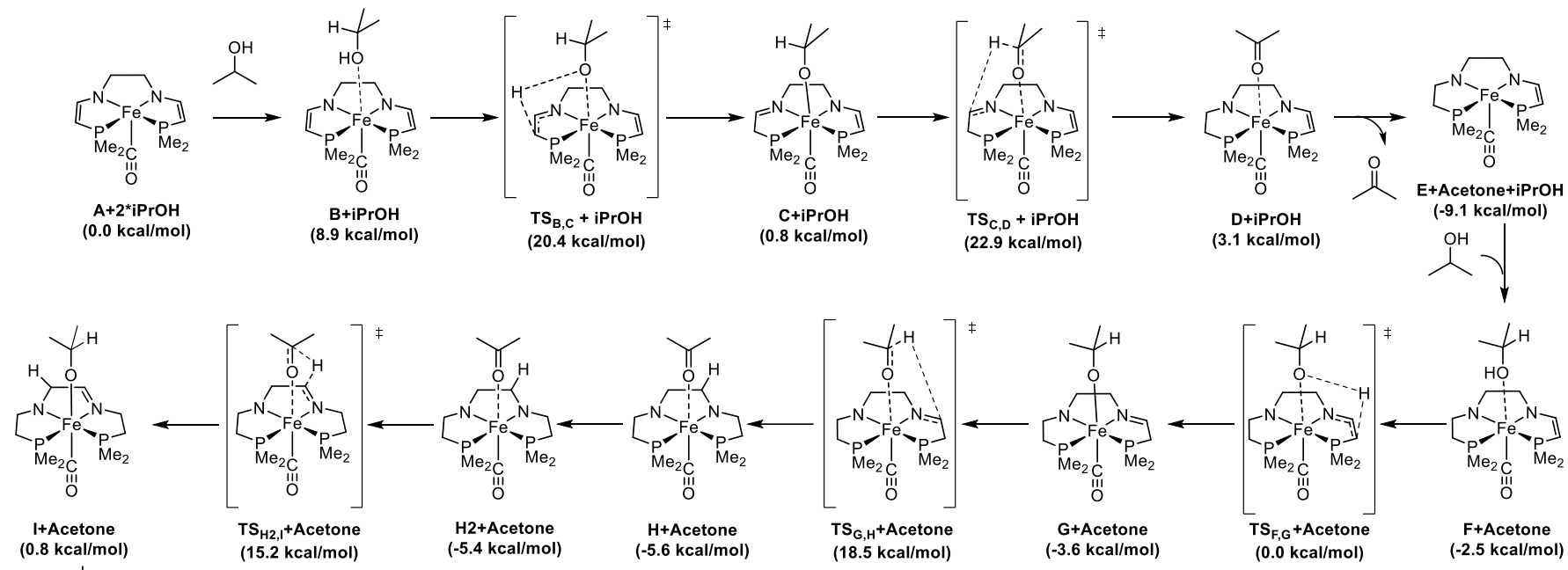

$\downarrow$

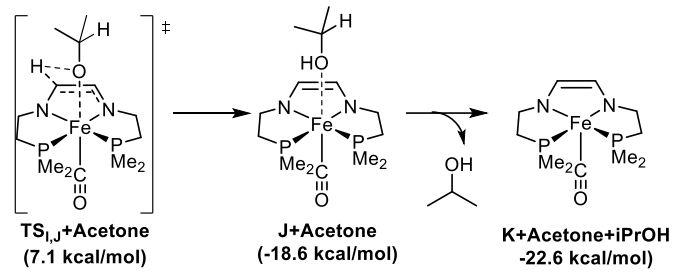

Figure 8. Free energy pathway for the formation of $\mathbf{K}$ (3a with Me, not Et) from $\mathbf{A}$ (2b with Me, not Et).

The calculations show that initial coordination of iPrOH in $\mathbf{B}$ leads to an increase in energy to $G^{\circ}=8.9$ $\mathrm{kcal} / \mathrm{mol}$, and that protonation of one of the eneamido functionalities by the coordinated alcohol occurs with a high energy barrier (TSB, $\mathbf{C} G^{\circ}=20.4 \mathrm{kcal} / \mathrm{mol}$ ). The resulting alkoxide complex $\mathbf{C}$ is very similar in energy to the bis-eneamido structure, $\Delta G^{\circ} 0.8 \mathrm{kcal} / \mathrm{mol}$. Following protonation, a hydride transfer from the $\mathrm{iPrO}$ ligand to the newly formed imine functionality is found to be energetically demanding, $\mathbf{T S}_{\mathbf{B}, \mathbf{C}} \Delta G^{\circ}{ }^{\circ} 22.9$ $\mathrm{kcal} / \mathrm{mol}$, and represents the rate determining step of the entire process. A partially reduced eneamido amido ligand with an acetone adduct is then generated, $\mathbf{D}$, and loss of the acetone gives $\mathbf{E}$, which is thermodynamically downhill from $\mathbf{A}$ (E $\left.\Delta G^{\circ}=-9.1 \mathrm{kcal} / \mathrm{mol}\right)$. It should be noted that up to this point, these calculations represent the activation process for ATH that have been calculated previously for very similar structures (with $\mathrm{PH}_{2}$ groups rather than $\mathrm{PMe}_{2}$ groups). ${ }^{30}$

Further reduction of the other imine moiety was then explored computationally. In a set of steps very similar to the activation process, an iPrOH adduct formed, $\mathbf{F}$, protonation of the eneamido occurred, $\mathbf{T S} \mathbf{F , G}$, followed by reduction of the imine moiety by the $\mathrm{iPrO}^{-}$ ligand, $\mathbf{T S}_{\mathbf{G}, \mathbf{H}}$. Once again, all of these steps have been investigated previously with very similar structures (with $\mathrm{PH}_{2}$ groups rather than $\mathrm{PMe}_{2}$ groups). ${ }^{30} \mathrm{In}$ addition, species like $\mathbf{H}$ have been independently synthesized, tested for ATH, and have been found to be inactive. $^{27}$

After the ligand was fully reduced, dehydrogenation of the diamine backbone was investigated. A minor conformational change from the acetone adduct $\mathbf{H}$ to give $\mathbf{H} 2$ positioned a backbone hydrogen optimally for hydride abstraction (Supporting Information Figure S1), and was accompanied by a very small change in energy $\left(\Delta G^{\circ}=-5.6 \mathrm{kcal} / \mathrm{mol}\right.$ for $\mathbf{H}$ versus $\Delta G^{\circ}=-5.4 \mathrm{kcal} / \mathrm{mol}$ for H2). The hydride transfer step from the tetradentate ligand to the coordinated acetone proceeded with a a modest energy barrier, $\mathbf{T S}_{\mathbf{H} 2, \mathbf{I}} \Delta G^{\circ}{ }^{\ddagger}=15.2 \mathrm{kcal} / \mathrm{mol}$, and gave an imine product much like $\mathbf{4}$, except with an alkoxide ligand. Subsequent deprotonation of the diamine backbone (TSI,J $\Delta G^{\circ}=7.1 \mathrm{kcal} / \mathrm{mol}$ ) and decoordination of iPrOH gave the desired product $\mathbf{K}$ with an energy of $\Delta G^{\circ}=-22.6 \mathrm{kcal} / \mathrm{mol}$. Overall, the entire process has a strong thermodynamic driving force with $\mathbf{K}$ being the lowest energy species.

Characterization of minor hydride products generated in the synthesis of 3a. As stated before, compounds 3a-b are the major compounds as determined by NMR spectroscopy, but can be isolated by dissolving the crude red residues with pentane or ether, followed by filtration of the precipitate. The precipitate, however, is red as well and can be dissolved 
in THF. $\mathrm{A}^{31} \mathrm{P}\left\{{ }^{1} \mathrm{H}\right\}$ NMR spectra of the precipitate from the synthesis of $\mathbf{3 a}$ displayed two pairs of doublets at 91.8 and $98.7 \mathrm{ppm}\left({ }^{2} J_{\mathrm{PP}}=31.4 \mathrm{~Hz}\right)$ and 85.7 and 87.9 ppm $\left({ }^{2} J_{\mathrm{PP}}=31.5 \mathrm{~Hz}\right)$. This indicated that these compounds were iron complexes with inequivalent phosphorus nuclei. The ${ }^{1} \mathrm{H}$ NMR spectrum was challenging to interpret but expansion of the negative chemical shift region showed the same two hydride signals observed in the original crude mixture at -3.54 ppm as a doublet of doublets $\left({ }^{2} J_{\mathrm{HP}}=54,75 \mathrm{~Hz}\right)$ and at $3.97 \mathrm{ppm}$ as a triplet $\left({ }^{2} J_{\mathrm{HP}}=65 \mathrm{~Hz}\right)$. Furthermore, the ${ }^{1} \mathrm{H}$ and ${ }^{11} \mathrm{~B}\left\{{ }^{1} \mathrm{H}\right\} \quad$ NMR spectra displayed $\mathrm{BPh}_{4}$ resonances, which implied that the iron hydride compounds (or least one of them) are cationic. The IR $(\mathrm{KBr})$ spectrum of the mixture of these two minor hydrides displayed an intense, but broad, $v_{\mathrm{CO}}$ absorption at $1909 \mathrm{~cm}^{-1}$; a minor shoulder was observed on this broad absorption at $1818 \mathrm{~cm}^{-1}$ and is attributed to the Fe$\mathrm{H}$ vibration.

Crystals of one of the iron hydride compounds, 6 were obtained and found to be suitable for X-ray diffraction (Figure 9). The diffraction data were good enough to allow the location of the hydride atom. Compound 6 is cationic and contains one $\mathrm{BPh}_{4}^{-}$anion; hence, the iron metal centre is still in the oxidation state $\mathrm{Fe}(\mathrm{II})$. The tetradentate ligand of $\mathbf{6}$ is completely reduced and the nitrogen atoms are protonated. This saturation makes the ligand more flexible and one arm of the tetradentate ligand has folded into a cis- $\alpha$ configuration in contrast to the trans configuration of 1a-b or 2a-b. The CO ligand in $\mathbf{6}$ is trans to one of the amino donors, while the hydride is trans to one of the phosphorus centres. Hence, the other hydride compound could be an isomer of $\mathbf{6}$ where the CO ligand is trans to a phosphine donor and the hydride is trans to a nitrogen atom of the P-N-N-P ligand, producing the triplet resonance with the similar $J_{\mathrm{HP}}$ coupling constants in the hydride region of the ${ }^{1} \mathrm{H}$ NMR spectrum

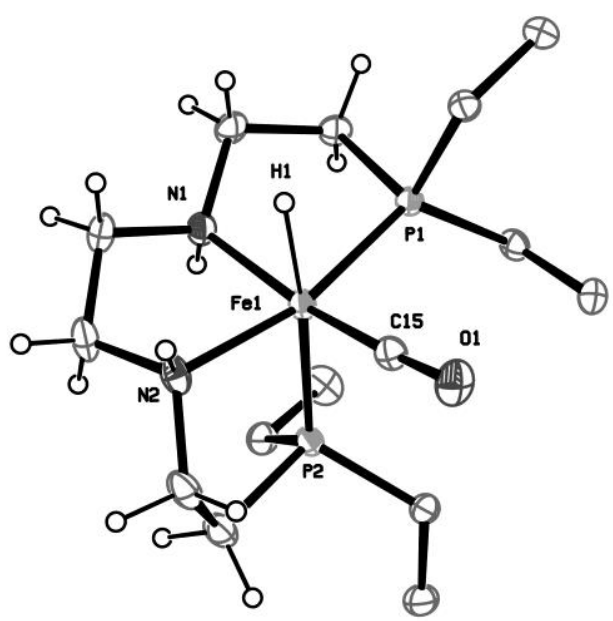

Figure 9. ORTEP plot (thermal ellipsoids at $30 \%$ probability) of $6 . \mathrm{BPh}_{4}$ anion and Et hydrogen atoms removed for clarity. Selected bond lengths (Å) and angles (deg): $\mathrm{Fe}(1)-\mathrm{C}(15)$ : 1.721(3); $\mathrm{Fe}(1)-\mathrm{N}(1)$ : 2.039(2); $\mathrm{Fe}(1)-\mathrm{P}(1): \quad 2.1600(7) ; \mathrm{Fe}(1)-\mathrm{P}(2): \quad 2.2616(8) ; \mathrm{Fe}(1)-\mathrm{H}(1)$ : 1.72(4); $\mathrm{O}(1)-\mathrm{C}(15): 1.165(3) ; \mathrm{N}(1)-\mathrm{C}(3): 1.477(3) ; \mathrm{N}(2)-\mathrm{C}(5): 1.481(4)$; $\mathrm{P}(1)-\mathrm{Fe}(1)-\mathrm{P}(2)$ : 105.75(3); $\mathrm{C}(15)-\mathrm{Fe}(1)-\mathrm{P}(1)$ : 92.59(8); $\mathrm{C}(15)-\mathrm{Fe}(1)-\mathrm{P}(2)$ : 93.61(9); $\mathrm{N}(2)-\mathrm{Fe}(1)-\mathrm{P}(2): 84.59(7)$.

The mechanism of formation of these minor iron hydride compounds is not straightforward since the compounds have obtained a total of five hydrogen atoms. Since iPrOH can only yield an even number of hydrogen atoms, there may be a side reaction to generate these minor iron hydride compounds or $\beta$-hydride elimination may be occurring. The mixture of iron hydride compounds were tested for ATH of acetophenone using the same conditions as with $\mathbf{2 a}$ as a catalyst $\left(\mathrm{C} / \mathrm{S}=1 / 200, \mathrm{~T}=50^{\circ} \mathrm{C}, 6 \mathrm{~mL}\right.$ iPrOH $)$ and were found to be inactive. Even with the addition of base ( 8 equiv. KOtBu) no catalysis was observed.

The reduction and acid-base reactions at the tetradentate ligands on iron that are reported here add to an increasing collection of modifications occurring at polydentate ligands containing amine or imine donors. Schneider et al. ${ }^{40}$ have discussed some remarkable examples of the versatility of chelating amido, imine, eneamido, and dieneamido ligands derived from the deprotonation or oxidative backbone functionalization of the ligand $\mathrm{HN}\left(\mathrm{CH}_{2} \mathrm{CH}_{2} \mathrm{PR}_{2}\right)_{2}$. We have shown how critical the placement of amido and eneamido donors in tetradentate P-N-N-P ligands on iron(II) is to catalytic activity of the complexes for the ATH of ketones and imines. 22, 32 Milstein and coworkers have taken full advantage of the acid-base properties of N-heterocyclecentred P-N-P ligands on ruthenium and iron for a range of impressive catalytic transformations. 16, 17, 41-47 Kirchner and coworkers have used the acid-base properties of related P-N-P ligands to activate dihydrogen at iron ${ }^{48}$ while Chirik and coworkers have reported acid-base and redox modifications of a P-N-P 
ligand on cobalt. ${ }^{49} \mathrm{~A}$ variety of other redox changes on the backbone of related tridentate ${ }^{50,51}$ and tetradentate ${ }^{52-}$ 54 imine- and amine-containing ligands have been reported.

\section{Conclusions}

There are (at least) two pathways that these iron carbonyl systems can pursue during catalysis of ATH: one is the productive catalytic cycle, while the other (or others) is a degradation pathway that leads to the formation of 3a-b (as well as deactivated iron-hydride compounds). The ethyl-substituted iron catalysts can more easily (or preferentially) form 3a-b than the phenyl-substituted catalysts, which explains why the phenyl-substituted iron catalysts can accommodate high loadings of substrate and even resume catalysis upon addition of more substrate when an initial equilibrium of the catalytic reaction had been reached. The formation of 3a-b is driven by the non-innocent behaviour of the tetradentate ligand. The major deactivated species that forms has a ligand that is partially reduced with the remaining double bond isomerized to form a $\mathrm{C}=\mathrm{C}$ bond between the amine donors of the tetradentate ligand. This species was identified by NMR studies and isolated as a bimetallic complex with $\mathrm{Ru}(\mathrm{II}) \mathrm{Cp}$ *. Two minor iron hydride species also formed concurrently as determined by NMR studies; one was isolated where the ligand was fully reduced and saturated and contained an iron hydride. None of the latter compounds were found to be transfer hydrogenation catalysts and are instead deactivated species inherently formed from their reaction with $\mathrm{iPrOH}$. Tetradentate ligand design that avoids these active hydrogens on the diamine will be the focus of future research towards catalysts that are more resistant to deactivation.

\section{Experimental}

\section{General Comments}

All procedures and manipulations involving airsensitive materials were performed under an argon or nitrogen atmosphere using Schlenk techniques or a glove-box with $\mathrm{N}_{2}$ (g). Solvents were degassed and dried using standard procedures prior to all manipulations and reactions. Deuterated solvents were purchased from Cambridge Isotope Laboratories and degassed and dried over activated molecular sieves prior to use. All other reagents used were purchased from commercial sources and utilized without further purifications. The complexes 1a-b, 2a-b, and $\left[\mathrm{RuCp}^{*}\left(\mathrm{NCCH}_{3}\right)_{3}\right]\left[\mathrm{PF}_{6}\right]$ were prepared by literature methods. NMR spectra were recorded at ambient temperature and pressure using Varian VnmrS-400 MHz $\left[{ }^{1} \mathrm{H}(400 \mathrm{MHz}),{ }^{13} \mathrm{C}\left\{{ }^{1} \mathrm{H}\right\}(100\right.$
MHz or $125 \mathrm{MHz})$ and $\left.{ }^{31} \mathrm{P}\left\{{ }^{1} \mathrm{H}\right\}(161 \mathrm{MHz})\right]$. The ${ }^{31} \mathrm{P}$ NMR spectra were referenced to $85 \% \mathrm{H}_{3} \mathrm{PO}_{4}(0 \mathrm{ppm})$. The elemental analyses were performed on a PerkinElmer $2400 \mathrm{CHN}$ elemental analyzer. We were unable to isolate the small amounts of $\mathbf{3 a}, \mathbf{3 b}$ and $\mathbf{5}$ in analytical purity.

Computational Details. Density functional theory calculations were performed using the Gaussian09 package $^{55}$ and the M06 hybrid functional. 56-58 Ruthenium was treated with the SDD relativistic effective core potential and associated basic set, ${ }^{59,60}$ while all other atoms were treated with the 6$31++\mathrm{G}(\mathrm{d}, \mathrm{p}) .{ }^{61-63}$ A pruned $(99,590)$ integration grid was used throughout (Grid=UltraFine). The substituents on phosphorus were replaced with methyl groups to reduce computational cost. Optimizations were performed in iPrOH using the integral equation formalism polarizable continuum model (IEF-PCM) ${ }^{64}$ with radii and nonelectrostatic terms from the SMD solvation model. ${ }^{65}$ Ground states were connected to their transition states by performing intrinsic reaction coordinate (IRC) calculations, ${ }^{66}$ and stationary points were characterized by normal-mode analysis. All structures were modelled as closed-shell singlet states. Full vibrational and thermochemical analyses (1 atm, 298 K) were performed on optimized structures to obtain solventcorrected free energies $\left(\mathrm{G}^{\circ}\right)$ and enthalpies $\left(\mathrm{H}^{\circ}\right)$. Optimized ground states were found to have zero imaginary frequencies, while transition states were found to have one imaginary frequency, except for TSF,G, which had one large imaginary frequency (proton transfer) and one very small imaginary frequency (molecule rocking). Attempts to find a transition state with only one imaginary frequency, including using a pruned $(225,974)$ integration grid (Grid=SuperFine), were unsuccessful.

$\left[\mathrm{Fe}(\mathrm{CO})\left(\mathrm{Et}_{2} \mathrm{PC}_{2} \mathrm{H}_{4} \mathrm{NC}_{2} \mathrm{H}_{2} \mathrm{NC}_{2} \mathrm{H}_{4} \mathrm{PEt}_{2}\right)\right]$, 3a. Method A: A vial was charged with $\mathbf{1 a}(50 \mathrm{mg}, 0.065 \mathrm{mmol})$, $\mathrm{NaO} i \operatorname{Pr}(15 \mathrm{mg}, 0.194 \mathrm{mmol})$ and benzene $(5 \mathrm{~mL})$. The mixture initially turned dark green and eventually turned dark red if left to stir for 5 hours. The solvent was removed, and the red residue was dissolved in $\mathrm{Et}_{2} \mathrm{O}$ and then filtered. 3a was isolated upon removal of the $\mathrm{Et}_{2} \mathrm{O}$ solvent. Yield: $17 \mathrm{mg}$ (70\%) Method B: 2a was dissolved in $i \mathrm{PrOH}$ (4 mL). After stirring for sufficient time the green solution turned pale orange. The solvent was removed with the aid of $\mathrm{Et}_{2} \mathrm{O}$ and dried overnight in vacuo to obtain a red residue. ${ }^{1} \mathrm{H} \mathrm{NMR}(400 \mathrm{MHz}$, $\left.\mathrm{C}_{6} \mathrm{D}_{6}\right) \delta: 0.63\left(\mathrm{~m}, 6 \mathrm{H}, \mathrm{CH}_{3}\right), 1.02\left(\mathrm{~m}, 6 \mathrm{H}, \mathrm{CH}_{3}\right), 1.68$ $\left(\mathrm{m}, 8 \mathrm{H}, \mathrm{CH}_{2} \mathrm{CH}_{3}\right), 2.08\left(\mathrm{~m}, 2 \mathrm{H}, \mathrm{PCH}_{2}\right), 2.20(\mathrm{~m}, 2 \mathrm{H}$ $\left.\mathrm{PCH}_{2}\right), 3.73\left(\mathrm{~m}, 2 \mathrm{H}, \mathrm{NCH}_{2}\right), 4.04\left(\mathrm{~m}, 2 \mathrm{H}, \mathrm{NCH}_{2}\right), 7.48$ $(\mathrm{s}, 2 \mathrm{H}, \mathrm{CH}) \cdot{ }^{13} \mathrm{C}\left\{{ }^{1} \mathrm{H}\right\}$ NMR $\left(100 \mathrm{MHz}, \mathrm{C}_{6} \mathrm{D}_{6}\right) \delta: 8.13$ $\left(\mathrm{CH}_{3}\right) 8.69\left(\mathrm{CH}_{3}\right) 23.4\left(\mathrm{CH}_{2} \mathrm{CH}_{3}\right), 33.0\left(\mathrm{PCH}_{2}\right), 56.1$ $\left(\mathrm{NCH}_{2}\right), \quad 135.8(\mathrm{CH}) .{ }^{31} \mathrm{P}\left\{{ }^{1} \mathrm{H}\right\} \quad \mathrm{NMR}(161 \mathrm{MHz}$, $\left.\mathrm{C}_{6} \mathrm{D}_{6}\right) \delta: 84.9 \mathrm{ppm}$. IR (KBr): $1850 \mathrm{~cm}^{-1}$. Anal. Calcd 
for $\mathrm{C}_{15} \mathrm{H}_{30} \mathrm{FeN}_{2} \mathrm{OP}_{2}$ : C, 48.40; $\mathrm{H}, 8.12 ; \mathrm{N}, 7.53$. Found: C, 51.87; H, 8.57; N, 6.36.

\section{$\left[\mathrm{Fe}(\mathrm{CO})\left(\mathrm{Et}_{2} \mathrm{PC}_{2} \mathrm{H}_{4} \mathrm{NC}\left(\mathrm{C}_{6} \mathrm{H}_{5}\right) \mathrm{C}\left(\mathrm{C}_{6} \mathrm{H}_{5}\right) \mathrm{NC}_{2} \mathrm{H}_{4} \mathrm{PEt}_{2}\right)\right]$,}

3b. Method A: A vial was charged with $\mathbf{1 b}(20 \mathrm{mg}$, $0.021 \mathrm{mmol}), \mathrm{NaO} i \operatorname{Pr}(14 \mathrm{mg}, 0.168 \mathrm{mmol})$ and benzene $(3 \mathrm{~mL})$. A solution of iPrOH $(0.010 \mathrm{~g}, 0.168 \mathrm{mmol})$ in benzene $(1 \mathrm{~mL})$ as well as a solution of acetone $(0.010$ $\mathrm{g}, 0.168 \mathrm{mmol})$ in benzene $(1 \mathrm{~mL})$ were then added. The mixture initially turned dark green and eventually turned dark red if left to stir for 3 weeks. The solvent was removed, and the red residue was dissolved in $\mathrm{Et}_{2} \mathrm{O}$ and then filtered. 3b was isolated upon removal of the $\mathrm{Et}_{2} \mathrm{O}$ solvent. Yield: $11 \mathrm{mg}(83 \%)$. ${ }^{1} \mathrm{H}$ NMR (400 MHz, $\left.\mathrm{C}_{6} \mathrm{D}_{6}\right) \delta: 0.63\left(\mathrm{~m}, 6 \mathrm{H}, \mathrm{CH}_{3}\right), 1.00\left(\mathrm{~m}, 6 \mathrm{H}, \mathrm{CH}_{3}\right), 1.62$ $\left(\mathrm{m}, 8 \mathrm{H}, \mathrm{CH}_{2} \mathrm{CH}_{3}\right), 2.02\left(\mathrm{~m}, 2 \mathrm{H}, \mathrm{PCH}_{2}\right), 2.16(\mathrm{~m}, 2 \mathrm{H}$ $\left.\mathrm{PCH}_{2}\right), 3.75\left(\mathrm{~m}, 2 \mathrm{H}, \mathrm{NCH}_{2}\right), 3.94\left(\mathrm{~m}, 2 \mathrm{H}, \mathrm{NCH}_{2}\right), 7.22$ (t, $4 \mathrm{H}, \mathrm{Ar}-\mathrm{CH}, J=6.3 \mathrm{~Hz}), 7.35(\mathrm{t}, 4 \mathrm{H}, \mathrm{Ar}-\mathrm{CH}, J=6.8$ $\mathrm{Hz}), 7.99$ (d, 2H, Ar-CH, $J=6.8 \mathrm{~Hz}) .{ }^{13} \mathrm{C}\left\{{ }^{1} \mathrm{H}\right\} \mathrm{NMR}$ $\left(100 \mathrm{MHz}, \mathrm{C}_{6} \mathrm{D}_{6}\right) \delta$ : $7.9\left(\mathrm{CH}_{3}\right) 8.4\left(\mathrm{CH}_{3}\right) 23.4(\mathrm{dd}$, $\mathrm{CH}_{2} \mathrm{CH}_{3}, J=12.5,11.2 \mathrm{~Hz}$ ), 32.8 (dd, $\mathrm{PCH}_{2}, J=13.8$, $12.9 \mathrm{~Hz}), 53.8\left(\mathrm{t}, \mathrm{NCH}_{2}, J=3.3 \mathrm{~Hz}\right), 126.3(\mathrm{Ar}-\mathrm{CH})$, 126.5 (Ar- $\mathrm{CH}), 134.8$ (Ar- $\mathrm{CH}), 139.2(C-\mathrm{Ar}), 147.5$ (Ar-C). ${ }^{31} \mathrm{P}\left\{{ }^{1} \mathrm{H}\right\}$ NMR (161 MHz, $\left.\mathrm{C}_{6} \mathrm{D}_{6}\right) \delta$ : $82.1 \mathrm{ppm}$. IR (KBr): $1878 \mathrm{~cm}^{-1}$.

Preparation of 5. To a vial containing 3a (17 mg, 0.046 $\mathrm{mmol})$ and THF (5 $\mathrm{mL})$, a slurry of $\left[\mathrm{Cp}^{*} \mathrm{Ru}\left(\mathrm{NCCH}_{3}\right)_{3}\right]\left[\mathrm{PF}_{6}\right](25 \mathrm{mg}, 0.050 \mathrm{mmol})$ and THF $(2 \mathrm{~mL})$ was added in one portion. The formerly red solution turned green-black upon stirring for $5 \mathrm{~min}$. The solution was filtered and dried in vacuo overnight. Yield: $15 \mathrm{mg}$ (43\%). $\quad{ }^{1} \mathrm{H}$ NMR (600 MHz, THF- $\left.d_{8}\right)$ $\delta: 0.92\left(\mathrm{~m}, 6 \mathrm{H}, \mathrm{CH}_{3}\right), 1.21\left(\mathrm{~m}, 6 \mathrm{H}, \mathrm{CH}_{3}\right), 1.56(\mathrm{~m}, 2 \mathrm{H}$, $\mathrm{CH}_{2} \mathrm{CH}_{3}$ ), 1.76 (by ${ }^{1} \mathrm{H}-{ }^{1} \mathrm{H}$ COSY, $\mathrm{CH}_{2} \mathrm{CH}_{3}$ ), 1.86 (by ${ }^{1} \mathrm{H}-{ }^{1} \mathrm{H}$ COSY, $\mathrm{CH}_{2} \mathrm{CH}_{3}$ ), 1.92 (by ${ }^{1} \mathrm{H}-{ }^{1} \mathrm{H}$ COSY, $\mathrm{CH}_{2} \mathrm{CH}_{3}$ ), 1.93 (s, $12 \mathrm{H}, \mathrm{CpCH}_{3}$ ), 1.98 (determined from ${ }^{1} \mathrm{H}_{-}{ }^{13} \mathrm{C}$ HSQC, $\left.\mathrm{CH}_{2} \mathrm{P}\right), 2.05\left(\mathrm{~s}, 3 \mathrm{H}, \mathrm{CpCH}_{3}\right), 2.64(\mathrm{~m}$, $\left.2 \mathrm{H}, \mathrm{CH}_{2} \mathrm{P}\right), 3.11\left(\mathrm{~m}, 2 \mathrm{H}, \mathrm{CH}_{2} \mathrm{~N}\right), 3.51\left(\mathrm{~m}, 2 \mathrm{H}, \mathrm{CH}_{2} \mathrm{~N}\right)$, $6.02(\mathrm{~s}, 1 \mathrm{H}, \mathrm{CHN}), 6.20(\mathrm{~s}, 1 \mathrm{H}, \mathrm{CHN}) .{ }^{13} \mathrm{C}\left\{{ }^{1} \mathrm{H}\right\} \mathrm{NMR}$ (150 MHz, THF-d8) $\delta: ~ 8.25\left(\mathrm{CH}_{3}\right), 8.47\left(\mathrm{CH}_{3}\right), 10.27$ $\left(\mathrm{CpCH}_{3}\right), 11.17\left(\mathrm{CpCH}_{3}\right), 22.43\left(\mathrm{dd}, J_{\mathrm{CP}}=10.5,13.5\right.$ $\mathrm{Hz}, \mathrm{CH}_{2} \mathrm{CH}_{3}$ ), 23.41 (dd, $J_{\mathrm{CP}}=7.5,10.5 \mathrm{~Hz}, \mathrm{CH}_{2} \mathrm{CH}_{3}$ ), $34.58\left(\mathrm{t}, J_{\mathrm{CP}}=14.7 \mathrm{~Hz}, C \mathrm{H}_{2} \mathrm{P}\right), 55.57\left(\mathrm{CH}_{2} \mathrm{~N}\right), 88.36$ $(C \mathrm{HN}), 98.81(C \mathrm{HN}), 221.22\left(\mathrm{t}, J_{\mathrm{CP}}=24.2 \mathrm{~Hz}, C \mathrm{O}\right)$. ${ }^{31} \mathrm{P}\left\{{ }^{1} \mathrm{H}\right\}$ NMR $\left(243 \mathrm{MHz}, \mathrm{THF}-d_{8}\right) \delta:-144.3\left(\mathrm{q}, J_{\mathrm{PF}}=\right.$ $710 \mathrm{~Hz}, P \mathrm{~F}_{6}$ ), minor: 72.4, major: 76.5 (s, $\left.P \mathrm{Et}_{2}\right)$. IR (KBr): major: $1958 \mathrm{~cm}^{-1}$; minor $1898 \mathrm{~cm}^{-1}$. MS (ESI, methanol/water; $\left.\mathrm{m} / \mathrm{z}^{+}\right)$: $\left.609.1\left(\mathrm{C}_{25} \mathrm{H}_{45} \mathrm{FeN}_{2} \mathrm{OP}_{2} \mathrm{Ru}\right]^{+}\right)$.

\section{Acknowledgements}

We thank NSERC Canada for a Discovery grant to R. H. M. and acknowledge the Canadian Foundation for Innovation, project number 19119, and the Ontario Research Fund for funding of the Centre for
Spectroscopic Investigation of Complex Organic Molecules and Polymers.

\section{Notes and references}

a Department of Chemistry, University of Toronto, Toronto, Ontario, M5S 3H6, Canada.

*E-mail: rmorris@chem.utoronto.ca

$\dagger$ Electronic Supplementary Information (ESI) available: Cif files giving crystal data for 4, 5, and 6. CCDC 1022766-1022768. Crystallographic data tables for $\mathbf{4 , 5}$, and $\mathbf{6}$. Optimized structures as well as selected bond lengths and angles for $\mathbf{H}, \mathbf{H 2}, \mathbf{T S}_{\mathbf{H 2}, \mathbf{I}}, \mathbf{I}$, $\mathbf{T S}_{\mathbf{I}, \mathbf{J}}$, and $\mathbf{J}$. Text giving the complete ref 55. Tables giving Cartesian coordinates and free energies for optimized structures. See DOI: $10.1039 / \mathrm{b} 000000 \mathrm{x} /$

1. H.-U. Blaser, C. Malan, B. Pugin, F. Spindler, H. Steiner and M. Studer, Adv. Synth. Catal., 2003, 345, 103-151.

2. F. Naud, F. Spindler, C. J. Rueggeberg, A. T. Schmidt and H.-U. Blaser, Org. Process Res. Dev., 2007, 11, 519-523.

3. R. M. Bullock, Catalysis without Precious Metals, Wiley-VCH, Hoboken, NJ, 2010.

4. R. M. Bullock, Science, 2013, 342, 1054-1055.

5. R. H. Morris, Chem. Soc. Rev., 2009, 38, 2282-2291.

6. K. Junge, K. Schroder and M. Beller, Chem. Commun., 2011, 47, 4849-4859.

7. F. Bozso, G. Ertl, M. Grunze and M. Weiss, J. Catal., 1977, 49, 18-41.

8. C. E. Housecroft and A. G. Sharpe, in Inorganic Chemistry, Pearson Education Ltd., Gosport, Second edn., 2005, pp. 617-624.

9. E. Alberico, P. Sponholz, C. Cordes, M. Nielsen, H.J. Drexler, W. Baumann, H. Junge and M. Beller, Angew. Chem. Int. Ed., 2013, 52, 14162-14166.

10. S. Werkmeister, K. Junge, B. Wendt, E. Alberico, H. Jiao, W. Baumann, H. Junge, F. Gallou and M. Beller, Angew. Chem. Int. Ed., 2014, 53, 8722-8726.

11. C. Bornschein, S. Werkmeister, B. Wendt, H. Jiao, E. Alberico, W. Baumann, H. Junge, K. Junge and M. Beller, Nat. Commun., 2014, 5, DOI: 10.1038/ncomms5111.

12. S. Chakraborty, H. Dai, P. Bhattacharya, N. T. Fairweather, M. S. Gibson, J. A. Krause and H. Guan, J. Am. Chem. Soc., 2014, 136, 7869-7872.

13. S. Chakraborty, W. W. Brennessel and W. D. Jones, J. Am. Chem. Soc., 2014, 136, 8564-8567.

14. E. A. Bielinski, P. O. Lagaditis, Y. Zhang, B. Q. Mercado, C. Würtele, W. H. Bernskoetter, N. Hazari and S. Schneider, J. Am. Chem. Soc., 2014, 136, 10234-10237.

15. P. O. Lagaditis, P. E. Sues, J. F. Sonnenberg, K. Y. Wan, A. J. Lough and R. H. Morris, J. Am. Chem. Soc., 2014, 136, 1367-1380.

16. R. Langer, G. Leitus, Y. Ben-David and D. Milstein, Angew. Chem. Int. Ed., 2011, 50, 2120-2124.

17. R. Langer, M. A. Iron, L. Konstantinovski, Y. Diskin-Posner, G. Leitus, Y. Ben-David and D. Milstein, Chem. Eur. J., 2012, 18, 7196-7209.

18. C. Sui-Seng, F. Freutel, A. J. Lough and R. H. Morris, Angew. Chem. Int. Ed., 2008, 47, 940-943.

19. C. Sui-Seng, F. N. Haque, A. Hadzovic, A.-M. PuÌtz, V. Reuss, N. Meyer, A. J. Lough, M. 
Zimmer-De Iuliis and R. H. Morris, Inorg. Chem., 2008, 48, 735-743.

20. A. Mikhailine, A. J. Lough and R. H. Morris, J. Am. Chem. Soc., 2009, 131, 1394-1395.

21. A. A. Mikhailine, M. I. Maishan and R. H. Morris, Org. Lett., 2012, 14, 4638-4641.

22. W. Zuo, A. J. Lough, Y. F. Li and R. H. Morris, Science, 2013, 342, 1080-1083.

$23 . \quad$ N. Meyer, A. J. Lough and R. H. Morris, Chem. Eur. J., 2009, 15, 5605-5610.

24. A. A. Mikhailine and R. H. Morris, Inorg. Chem., 2010, 49, 11039-11044.

$25 . \quad$ P. O. Lagaditis, A. J. Lough and R. H. Morris, Inorg. Chem., 2010, 49, 10057-10066.

26. P. E. Sues, A. J. Lough and R. H. Morris, Organometallics, 2011, 30, 4418-4431.

27. A. A. Mikhailine, M. I. Maishan, A. J. Lough and R. H. Morris, J. Am. Chem. Soc., 2012, 134, 1226612280 .

$28 . \quad$ P. O. Lagaditis, A. J. Lough and R. H. Morris, J. Am. Chem. Soc., 2011, 133, 9662-9665.

29. J. F. Sonnenberg, N. Coombs, P. A. Dube and R. H. Morris, J. Am. Chem. Soc., 2012, 134, 5893-5899.

30. D. E. Prokopchuk and R. H. Morris, Organometallics, 2012, 31, 7375-7385.

31. D. E. Prokopchuk, J. F. Sonnenberg, N. Meyer, M. Zimmer-De Iuliis, A. J. Lough and R. H. Morris, Organometallics, 2012, 31, 3056-3064.

32. P. E. Sues, K. Z. Demmans and R. H. Morris, Dalton Trans., 2014, 43, 7650-7667.

33. P. M. Álvarez, D. McLurgh and P. Plucinski, Ind. Eng. Chem. Res., 2002, 41, 2153-2158.

34. S. Shwan, R. Nedyalkova, J. Jansson, J. Korsgren, L. Olsson and M. Skoglundh, Ind. Eng. Chem. Res., 2012, 51, 12762-12772.

35. A. D. Pienaar and A. de Klerk, Ind. Eng. Chem. Res., 2008, 47, 4962-4965.

36. R. Abbel, K. Abdur-Rashid, M. Faatz, A. Hadzovic, A. J. Lough and R. H. Morris, J. Am. Chem. Soc., 2005, 127, 1870-1882.

$37 . \quad$ D. J. Harrison, A. G. De Crisci, A. J. Lough, M. J. Kerr and U. Fekl, Inorg. Chem., 2008, 47, 1019910201.

38. X. D. He, B. Chaudret, F. Dahan and Y. S. Huang, Organometallics, 1991, 10, 970-979.

39. CRC Handbook of Chemistry and Physics Haynes, W., Ed.; CRC Press: Boca Raton, FL, 2012-2013; Vol. 2093, p 2186.

40. S. Schneider, J. Meiners and B. Askevold, Eur. J. Inorg. Chem., 2012, 412-429.

41. B. Gnanaprakasam, E. Balaraman, Y. Ben-David and D. Milstein, Angew. Chem. Int. Ed., 2011, 50, 12240-12244.

42. C. Gunanathan and D. Milstein, Acc. Chem. Res., 2011, 44, 588-602.

43. C. Gunanathan and D. Milstein, Science, 2013, 341 249-+.

44. D. Srimani, E. Balaraman, P. Hu, Y. Ben-David and D. Milstein, Adv. Syn. Catal., 2013, 355, 2525-2530.

45. D. Srimani, Y. Diskin-Posner, Y. Ben-David and D. Milstein, Angew. Chem. Int. Ed., 2013, 52, 1413114134.

46. J. R. Khusnutdinova, Y. Ben-David and D. Milstein, J. Am. Chem. Soc., 2014, 136, 2998-3001.

47. T. Zell, Y. Ben-David and D. Milstein, Angew. Chem. Int. Ed., 2014, 53, 4685-4689.

48. B. Bichler, C. Holzhacker, B. Stoger, M. Puchberger, L. F. Veiros and K. Kirchner, Organometallics, 2013, 32, 4114-4121.
49. S. P. Semproni, C. Milsmann and P. J. Chirik, J. Am. Chem. Soc. , 2014, 136, 9211-9224.

50. S. C. E. Stieber, C. Milsmann, J. M. Hoyt, Z. R. Turner, K. D. Finkelstein, K. Wieghardt, S. DeBeer and P. J. Chirik, Inorg. Chem., 2012, 51, 3770-3785.

51. A. M. Tondreau, S. C. E. Stieber, C. Milsmann, E. Lobkovsky, T. Weyhermueller, S. P. Semproni and P. J. Chirik, Inorg. Chem., 2013, 52, 635-646.

52. F. N. Haque, A. J. Lough and R. H. Morris, Inorg. Chim. Acta, 2008, 361, 3149-3158.

53. D. E. Prokopchuk, A. J. Lough and R. H. Morris, Dalton Trans., 2011, 40, 10603-10608.

54. R. E. Rodriguez-Lugo, M. Trincado, M. Vogt, F. Tewes, G. Santiso-Quinones and H. Gruetzmacher, Nature Chem., 2013, 5, 342-347.

55. M. J. Frisch, 2010, et al. Gaussian 09.

56. A. D. Kulkarni and D. G. Truhlar, J. Chem. Theory Comput., 2011, 7, 2325-2332.

57. Y. Zhao and D. G. Truhlar, J. Chem. Phys., 2006, 125, 194101-194118.

58. Y. Zhao and D. G. Truhlar, Theor. Chem. Acc., 2008, 120, 215-241.

59. D. Andrae, U. Häußermann, M. Dolg, H. Stoll and H. Preuß, Theor. Chim. Acta, 1990, 77, 123-141.

$60 . \quad$ T. Leininger, A. Nicklass, H. Stoll, M. Dolg and P. Schwerdtfeger, J. Chem. Phys., 1996, 105, 10521059.

61. T. Clark, J. Chandrasekhar, G. W. Spitznagel and P. V. R. Schleyer, J. Comput. Chem., 1983, 4, 294-301.

62. M. J. Frisch, J. A. Pople and J. S. Binkley, J. Chem. Phys., 1984, 80, 3265-3269.

63. B. J. Lynch, Y. Zhao and D. G. Truhlar, J. Phys. Chem. A, 2003, 107, 1384-1388.

64. J. Tomasi, B. Mennucci and E. Cancès, J. Mol. Struct. THEOCHEM, 1999, 464, 211-226.

65. A. V. Marenich, C. J. Cramer and D. G. Truhlar, J. Phys. Chem. B, 2009, 113, 6378-6396.

66. K. Fukui, Acc. Chem. Res., 1981, 14, 363-368.

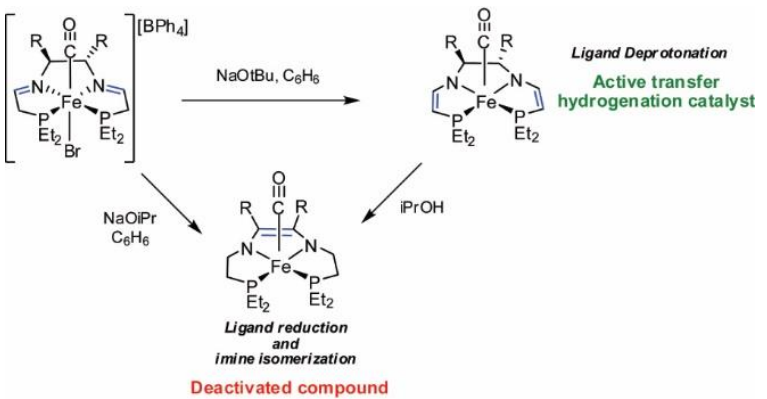




\title{
Supporting Information for: Exploring the Decomposition
}

\author{
Pathways of Iron Asymmetric Transfer Hydrogenation
}

\section{Catalysts}

Paraskevi O. Lagaditis, Peter E. Sues, Alan J. Lough, and Robert H. Morris*

Department of Chemistry, University of Toronto, Toronto, Ontario M5S 3H6, Canada

\section{Table of Contents:}

Crystallographic Data Tables for $\mathbf{4 , 5}$, and $\mathbf{6}$

Optimized Geometries of $\mathbf{H}, \mathbf{H 2}$, TSH2,I, I, TSI,J, and J

Full Gaussian09 Reference 
Table S1. Crystallographic Data Tables for 4, 5, and 6

\begin{tabular}{|c|c|c|c|}
\hline & 4 & 5 & 6 \\
\hline empirical formula & $\mathrm{C}_{15} \mathrm{H}_{32} \mathrm{Br}_{0.5} \mathrm{Cl}_{1.5} \mathrm{FeN}_{2} \mathrm{OP}_{2}$ & $\mathrm{C}_{25} \mathrm{H}_{44} \mathrm{~F}_{6} \mathrm{FeN}_{2} \mathrm{OP}_{3} \mathrm{Ru}$ & $\mathrm{C}_{39} \mathrm{H}_{55} \mathrm{BFeN}_{2} \mathrm{OP}_{2}$ \\
\hline FW & 467.35 & 752.45 & 696.45 \\
\hline lattice type & Monoclinic & Monoclinic & Triclinic \\
\hline space group & $P 21 / \mathrm{n}$ & $P 2{ }_{1} / \mathrm{c}$ & $P_{-1}$ \\
\hline$T, \mathrm{~K}$ & $150(1)$ & $150(1)$ & $150(1)$ \\
\hline$a, \AA$ & $13.1588(5)$ & $8.4983(2)$ & $10.3749(4)$ \\
\hline$b, \AA$ & $7.6800(2)$ & $21.6914(8)$ & $11.5650(4)$ \\
\hline$c, \AA$ & $21.6873(7)$ & $17.3708(6)$ & $16.1355(7)$ \\
\hline$\alpha, \operatorname{deg}$ & 90 & 90 & $106.437(2)$ \\
\hline$\beta, \operatorname{deg}$ & $106.382(2)$ & $93.653(1)$ & $101.679(2)$ \\
\hline$\gamma, \operatorname{deg}$ & 90 & 90 & $92.517(2)$ \\
\hline$V, \AA^{3}$ & $2102.7(1)$ & $3195.6(2)$ & $1807.8(1)$ \\
\hline$Z$ & 4 & 4 & 2 \\
\hline$\rho_{\text {calc }} / \mathrm{Mg} \mathrm{m}^{-3}$ & 1.476 & 1.564 & 1.279 \\
\hline$\mu(\mathrm{Mo}, \mathrm{K} \alpha), \mathrm{mm}^{-1}$ & 2.015 & 1.134 & 0.539 \\
\hline$F(000)$ & 972 & 1540 & 744 \\
\hline cryst size, $\mathrm{mm}^{3}$ & $0.30 \times 0.14 \times 0.12$ & $0.14 \times 0.10 \times 0.05$ & $0.25 \times 0.25 \times 0.20$ \\
\hline range $\theta$ collected, deg & 2.83 to 27.45 & 1.88 to 26.99 & 1.85 to 26.99 \\
\hline reflns collected/unique & $11795 / 4764$ & $28470 / 6938$ & $26212 / 7820$ \\
\hline abs cor & \multicolumn{3}{|c|}{ Semi-empirical from equivalents } \\
\hline max and min transmn coeff. & 0.744 and 0.679 & 0.7455 and 0.6959 & 0.890 and 0.771 \\
\hline goodness of fit & 1.047 & 1.010 & 1.036 \\
\hline$R_{1}(I>2 s(I))$ & 1.019 & 0.0531 & 0.0556 \\
\hline$w R_{2}$ (all data) & 0.1162 & 0.1391 & 0.1203 \\
\hline peak and hole, e $\AA^{-3}$ & 0.714 and -0.525 & 1.290 and -0.951 & 0.313 and -0.326 \\
\hline
\end{tabular}




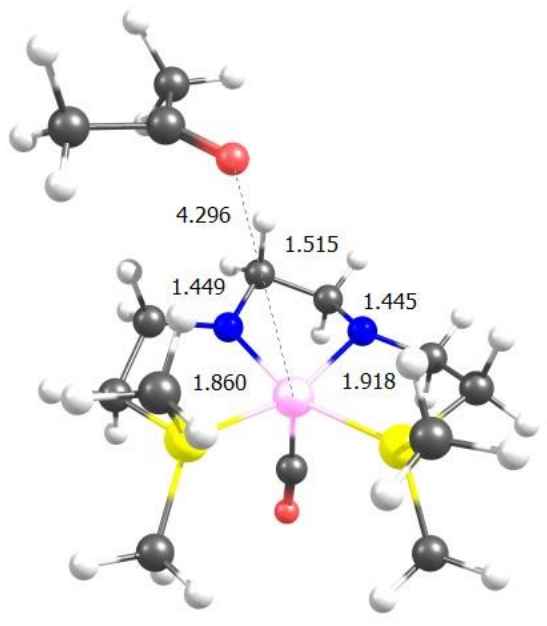

$\mathbf{H}$

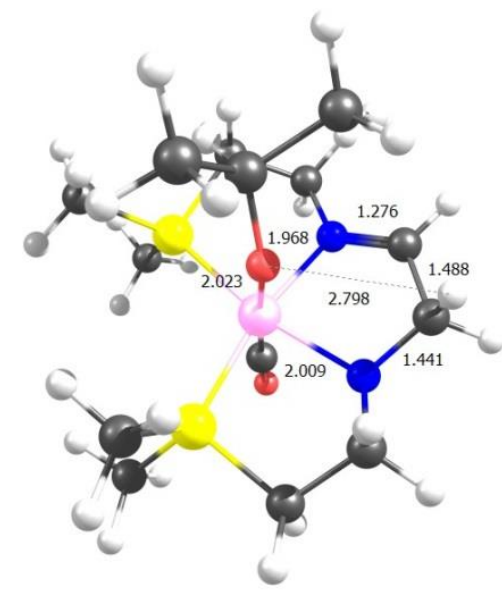

I

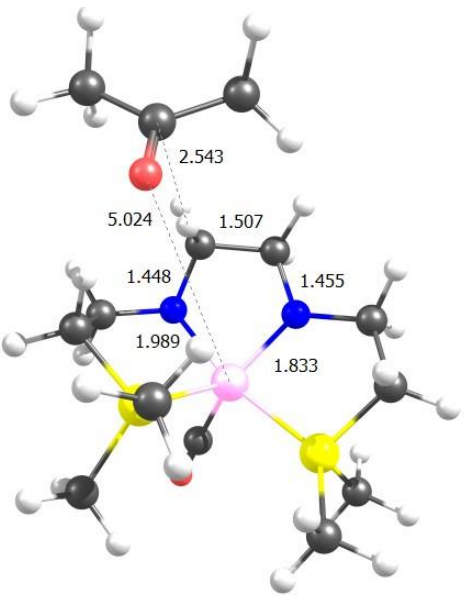

H2

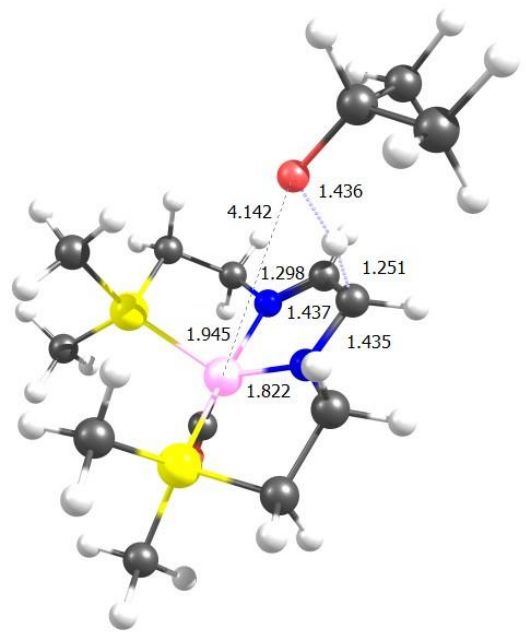

TS

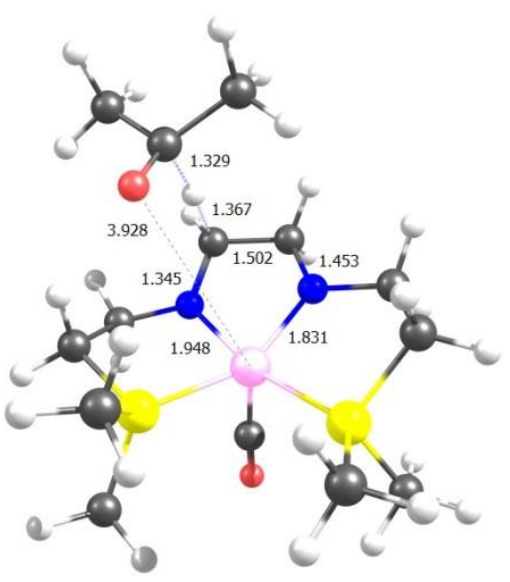

$\mathrm{TS}_{\mathrm{H} 2, \mathrm{I}}$

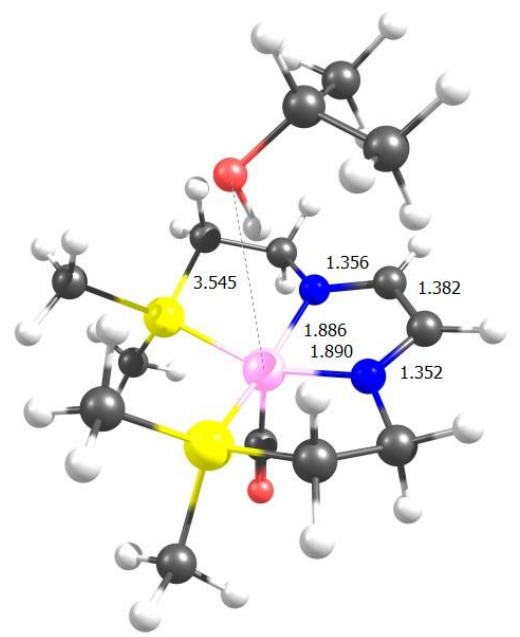

$\mathbf{J}$

Figure S1. Optimized structures, as well as selected bond lengths and angles for $\mathbf{H}, \mathbf{H 2}$, TSH2,I, $\mathbf{I}, \mathbf{T S}_{\mathbf{I}, \mathbf{J}}$, and $\mathbf{J}$. 
Full Gaussian09 Reference. Gaussian 09, Revision B.01, M. J. Frisch, G. W. Trucks, H. B. Schlegel, G. E. Scuseria, M. A. Robb, J. R. Cheeseman, G. Scalmani, V. Barone, B. Mennucci, G. A. Petersson, H. Nakatsuji, M. Caricato, X. Li, H. P. Hratchian, A. F. Izmaylov, J. Bloino, G. Zheng, J. L. Sonnenberg, M. Hada, M. Ehara, K. Toyota, R. Fukuda, J. Hasegawa, M. Ishida, T. Nakajima, Y. Honda, O. Kitao, H. Nakai, T. Vreven, J. A. Montgomery, Jr., J. E. Peralta, F. Ogliaro, M. Bearpark, J. J. Heyd, E. Brothers, K. N. Kudin, V. N. Staroverov, R. Kobayashi, J. Normand, K. Raghavachari, A. Rendell, J. C. Burant, S. S. Iyengar, J. Tomasi, M. Cossi, N. Rega, J. M. Millam, M. Klene, J. E. Knox, J. B. Cross, V. Bakken, C. Adamo, J. Jaramillo, R. Gomperts, R. E. Stratmann, O. Yazyev, A. J. Austin, R. Cammi, C. Pomelli, J. W. Ochterski, R. L. Martin, K. Morokuma, V. G. Zakrzewski, G. A. Voth, P. Salvador, J. J. Dannenberg, S. Dapprich, A. D. Daniels, Ö. Farkas, J. B. Foresman, J. V. Ortiz, J. Cioslowski, and D. J. Fox, Gaussian, Inc., Wallingford CT, 2010. 


\section{Cartesian Coordinates $(\AA)$ and Free Energies $\left(G^{\circ}{ }_{\text {solv }}, \mathrm{kcal} / \mathrm{mol}\right)$ of Optimized Structures}

\section{Acetone}

$G_{\text {solv }}^{\circ}-192.993877$

C -0.000003853

C $\quad-1.272544551$

H $\quad-2.136658089$

$\mathrm{H} \quad-1.234318374$

$\mathrm{H} \quad-1.386011271$

C 1.272576069

$\mathrm{H} \quad 2.136669530$

$\mathrm{H} \quad 1.234490029$

$\mathrm{H} \quad 1.386034894$

O $\quad-0.000046589$

\section{iPrOH}

$G^{\circ}{ }^{\circ}$ solv -194.168373

H 0.965992234

H $\quad 0.007881553$

C $\quad-0.002739674$

C $\quad 1.155074907$

$\mathrm{H} \quad 2.117999670$

$\mathrm{H} \quad 1.079634790$

$\mathrm{H} \quad 1.158919422$

C -1.335475299

$\mathrm{H} \quad-2.157781411$

$\mathrm{H}-1.364836614$

$\mathrm{H}-1.500424452$

O $\quad 0.098931901$

\section{A}

$G_{\text {solv }}^{\circ}-2561.799638$

$\mathrm{Fe} \quad 0.020276966$

P $\quad 1.674883872$

O 0.150088445

N $\quad-1.098566476$

N 1.395346905

C $\quad-2.430570272$

H $\quad-3.005891793$

C $\quad 2.697067729$

H $\quad 3.440147058$

C $\quad 3.082201216$

H 4.121073122

C $\quad 0.099099182$

C $\quad 1.674227972$

$\mathrm{H} \quad 2.650377087$

$\mathrm{H} \quad 0.896057503$

H 1.479408325
0.181890213

$-0.612209784$

0.033938513

$-1.403679246$

$-1.112979661$

$-0.612147453$

0.034076613

$-1.403459039$

$-1.113075823$

1.402497603

\subsection{7}

0.090664015

0.040712764

$-0.817307440$

$-0.399902814$

$-1.832309277$

$-0.885604178$

$-0.504245725$

0.139615073

$-0.563516254$

$-1.509722556$

1.365743592

0.336379351

$-1.112871275$

$-0.324635549$

1.833995807

1.641240655

1.703071794

2.613282021

1.298505320

2.106240272

$-0.019847621$

$-0.334640164$

$-0.075772549$

$-1.770889224$

$-2.215411951$

$-2.533835672$

$-0.949951904$
$-0.000012835$

$-0.003100390$

$-0.176593310$

$-0.761515738$

0.967493854

0.003095112

0.176422322

0.761685979

$-0.967414208$

0.000003722

0.074787659

1.469227521

0.365834970

$-0.101901826$

0.220228506

0.307700716

$-1.197940354$

$-0.089890287$

0.241884257

$-1.185963411$

0.314207518

$-0.161048693$

0.100379053

$-0.290522178$

2.895692890

$-0.258576608$

$-0.130284594$

$-0.448981066$

$-0.662209155$

$-0.121281538$

$-0.112320888$

$-0.148861333$

$-0.227152832$

1.752535431

$-2.004705985$

$-2.236597843$

$-2.124725153$

$-2.705350030$
C

$\mathrm{H}$

$\mathrm{H}$

$\mathrm{H}$

$\mathrm{P} \quad-1.875548281$

C $\quad-2.510323914$

$\mathrm{H} \quad-3.492182861$

H $\quad-1.815886150$

$\mathrm{H} \quad-2.608672358$

C $\quad-1.994361819$

H -1.646431360

H $\quad-1.369193193$

H $\quad-3.033928958$

C 0.949633593

H 0.891408929

$\mathrm{H} \quad 1.641089475$

C -0.436998806

$\mathrm{H} \quad-0.352175531$

$\mathrm{H} \quad-1.000360185$

C -3.047619837

$\mathrm{H} \quad-4.122902155$

B

$G_{\text {solv }}^{\circ}-2756.060980$

$\mathrm{Fe} \quad-0.274489370$

P $\quad 0.615895186$

O $\quad-2.223034575$

$\mathrm{N}$

$-0.662665671$

$\mathrm{N}$

1.182072419

C -1.766457984

H $\quad-2.049631208$

C 2.176061262

H 3.043609452

C 2.144831412

$\mathrm{H} \quad 2.893629861$

C $\quad-1.425124106$

C 0.935140243

$\mathrm{H} \quad 1.622286791$

$\mathrm{H} \quad-0.016669940$

$\mathrm{H} \quad 1.360038083$

C $\quad-0.269371894$

$\mathrm{H} \quad-1.255424688$

H 0.316606582
$-2.612693449$

$-3.313061019$

$-3.105073484$

$-2.351036736$

$-0.849737935$

$-1.930384242$

$-2.336059401$

$-2.761952808$

$-1.354256922$

$-1.947870396$

$-1.414769494$

$-2.837425480$

$-2.263893610$

3.002800683

3.191073011

3.744710489

3.115224644

3.310147015

3.952364007

0.482118177

0.351677183
0.700716124

0.582824614

0.370222859

1.760197886

$-0.144418565$

1.187600374

0.914188846

1.361710690

2.114399582

$-1.608041683$

$-2.500258232$

$-1.457363690$

$-1.761661696$

0.118983671

1.206866109

$-0.309535066$

$-0.489296285$

$-1.573314654$

$-0.048604391$

$-0.378031542$

$-0.484392893$
0.005383016

2.060659309

1.086399421

$-1.816777285$

$-0.168127727$

$-2.435008529$

$-3.388133120$

0.718736451

0.513587935

1.871369935

2.656262622

0.682445263

2.779053790

3.630760989

3.137607529

2.046260528

3.487385113

3.625067857

4.406069362
$-0.397095635$

$-0.011814331$

$-2.214089156$

$-0.983643090$

$-1.683455035$

$-0.523638451$

$-0.991413264$

$-1.686135937$

$-2.330790399$

$-0.918005928$

$-1.023149309$

$-1.466490833$

1.646196125

1.558813229

2.059595605

2.336324042

$-0.765799501$

$-0.302313315$

$-0.632559269$ 


$\begin{array}{lrrr}\mathrm{H} & -0.404603770 & 3.312634074 & -1.839259385 \\ \mathrm{P} & -1.929377784 & -0.329139110 & 1.099513285 \\ \mathrm{C} & -3.373206226 & 0.797237530 & 1.167487738 \\ \mathrm{H} & -4.139451972 & 0.402598224 & 1.846711884 \\ \mathrm{H} & -3.052278730 & 1.783073070 & 1.529889729 \\ \mathrm{H} & -3.813695051 & 0.915218704 & 0.171351909 \\ \mathrm{C} & -1.521900745 & -0.462235396 & 2.882719115 \\ \mathrm{H} & -0.710653147 & -1.182148334 & 3.030204852 \\ \mathrm{H} & -1.202926410 & 0.517965150 & 3.260647203 \\ \mathrm{H} & -2.404737760 & -0.790535770 & 3.446244085 \\ \mathrm{C} & 1.285815216 & -1.470266667 & -2.322751175 \\ \mathrm{H} & 1.663825025 & -1.393176411 & -3.355107036 \\ \mathrm{H} & 1.983393700 & -2.127221769 & -1.770178867 \\ \mathrm{C} & -0.103033604 & -2.095504049 & -2.297786693 \\ \mathrm{H} & -0.056972568 & -3.177554077 & -2.501646762 \\ \mathrm{H} & -0.723587842 & -1.637075237 & -3.091220677 \\ \mathrm{C} & -2.505119276 & -1.924880354 & 0.519177414 \\ \mathrm{H} & -3.334293383 & -2.473716083 & 0.964565927 \\ \mathrm{C} & 2.208658036 & -1.532799659 & 1.717234281 \\ \mathrm{H} & 2.011497907 & -2.360345260 & 2.418950058 \\ \mathrm{C} & 2.591887591 & -0.304653475 & 2.499907769 \\ \mathrm{H} & 2.833372215 & 0.521237467 & 1.816741824\end{array}$

TSB,C

$\begin{array}{lccc}G^{\circ}{ }_{\text {solv }} & -2756.037262 & & \\ \mathrm{Fe} & -0.199883101 & 0.168856986 & -0.412721005 \\ \mathrm{P} & 1.202243100 & 1.811697067 & 0.251066796 \\ \mathrm{O} & -1.391801804 & 1.949497569 & -2.352396769 \\ \mathrm{~N} & -1.003171799 & -1.461997791 & -1.151498489 \\ \mathrm{~N} & 1.282943382 & -0.399915291 & -1.550133844 \\ \mathrm{C} & -1.776210848 & -2.171886758 & -0.399587873 \\ \mathrm{H} & -2.089677029 & -3.175756224 & -0.714726346 \\ \mathrm{C} & 2.461422570 & 0.206562662 & -1.454039901 \\ \mathrm{H} & 3.286125966 & -0.170902080 & -2.076421086 \\ \mathrm{C} & 2.675999621 & 1.280739200 & -0.603713415 \\ \mathrm{H} & 3.623968232 & 1.817259873 & -0.579104789 \\ \mathrm{C} & -0.897589725 & 1.230873997 & -1.578943036 \\ \mathrm{C} & 1.558325280 & 2.101077105 & 2.025158765 \\ \mathrm{H} & 2.460183846 & 2.718836107 & 2.127729546 \\ \mathrm{H} & 0.714666676 & 2.635875926 & 2.479808881 \\ \mathrm{H} & 1.706942170 & 1.157466005 & 2.556192590 \\ \mathrm{C} & 0.854942129 & 3.538593807 & -0.273508323 \\ \mathrm{H} & -0.080711975 & 3.893136187 & 0.179003511 \\ \mathrm{H} & 1.673329752 & 4.202355388 & 0.034193306 \\ \mathrm{H} & 0.760896489 & 3.586009861 & -1.363963302 \\ \mathrm{P} & -2.071997149 & 0.179970145 & 0.852282532 \\ \mathrm{C} & -3.663875822 & 0.748697948 & 0.158963336\end{array}$

H

H

C

$\mathrm{H}$

$\mathrm{H}$

$\mathrm{H}$

C

C

$\mathrm{H}$

C

$\mathrm{H}$

$\mathrm{H}$

C

$\mathrm{H}$

C

C

$\mathrm{H}$

C

$\mathrm{H}$

$\mathrm{H}$

$\mathrm{H}$

C

$\mathrm{H}$

$\mathrm{H}$

$\mathrm{H}$

$\mathrm{H}$

O

C

$G^{\circ}{ }_{\text {solv }}-2756.072483$

$\mathrm{Fe}$

\section{$\mathrm{P}$}

$\mathrm{O}$

$\mathrm{O}$

$\mathrm{N}$

$\mathrm{N}$

C

$\mathrm{H}$

C

$\mathrm{H}$

$\mathrm{H}$

C

$\mathrm{H}$

C

C

C

$\mathrm{H}$

$\mathrm{H}$

$\mathrm{H}$

C
$-4.498514463$

$-3.684159636$

$-3.788101314$

$-2.159938957$

$-1.253933176$

$-2.244065074$

$-3.036093404$

1.063420873

1.420855408

1.604394276

$-0.439322737$

$-0.638937241$

$-0.922168071$

$-2.097643274$

$-2.884242177$

1.283340974

0.765036274

2.480935754

3.018873384

2.171575850

3.184009717

1.748353756

2.334281450

0.897857425

2.383726989

0.355223902

$-0.861584367$
0.236416300

2.102291520

1.731200608

$-1.290679508$

0.923295340

$-2.386216683$

$-3.205265402$

2.053238879

2.356445060

2.848805326

3.807359386

1.118578885

1.926741603

2.915481728

1.430336412

1.319127760

3.333351802
0.405023098

1.844360569

0.349477432

0.730883762

0.428472868

1.823664325

0.296469452

$-1.553845260$

$-1.376910502$

$-2.437857926$

$-1.856162312$

$-2.914784362$

$-1.247834000$

$-1.652771015$

$-2.156111624$

$-2.026373778$

$-2.667240828$

$-1.401669346$

$-0.731425904$

$-0.821727150$

$-2.174898136$

$-2.945377824$

$-3.777579810$

$-3.370416546$

$-2.400014313$

$-1.044731311$

$-1.581029143$
0.782327093

0.109045894

$-0.854666586$

2.587827770

3.123328263

2.617373180

3.086086938

$-2.405456620$

$-3.432819324$

$-2.029182455$

$-2.430557365$

$-2.652760818$

$-3.210744783$

0.915261001

1.482659696

1.703781897

2.450412064

2.399539710

1.712113909

3.278609030

2.738385021

0.586290106

0.999239531

0.037155481

$-0.123256472$

1.301820166

1.354431053
0.024759009 $-0.009074141$

1.457340861

$-0.363315828$

$-1.667282415$

0.290680251

$-0.007339141$

$-2.182086363$

$-3.175308556$

$-1.505094578$

$-1.898356863$

0.904875644

$-0.146923652$

$-0.247533457$

0.747742196

$-1.024463103$

1.346582407
$-0.396814585$

0.875458871

$-2.435420547$

$-1.580875068$

$-1.124727110$

$-1.591681656$

$-2.258192895$

$-0.654399806$

$-1.017673865$

0.256531198

0.593667398

$-1.612000660$

2.695215460

3.161544465

3.094293091

2.934237881

0.766068445 


$\begin{array}{lrrr}\mathrm{H} & 2.912465349 & 2.265931530 & 1.195772982 \\ \mathrm{H} & 4.244695489 & 1.086271133 & 1.319759788 \\ \mathrm{H} & 3.602935098 & 1.537684208 & -0.278581972 \\ \mathrm{P} & -0.946606440 & 1.851135800 & 0.154144822 \\ \mathrm{C} & -0.474084151 & 3.458838355 & -0.582282694 \\ \mathrm{H} & -1.199608718 & 4.239637952 & -0.323068354 \\ \mathrm{H} & 0.517425435 & 3.754465305 & -0.216891068 \\ \mathrm{H} & -0.426835209 & 3.366820972 & -1.673564691 \\ \mathrm{C} & -1.404630018 & 2.350331507 & 1.850571560 \\ \mathrm{H} & -1.734228184 & 1.488234944 & 2.438852520 \\ \mathrm{H} & -0.519414829 & 2.783592458 & 2.332710444 \\ \mathrm{H} & -2.200935366 & 3.104776775 & 1.829402840 \\ \mathrm{C} & -0.075185478 & -2.451998342 & -1.812888356 \\ \mathrm{H} & 0.369998079 & -3.126839444 & -2.562237917 \\ \mathrm{H} & -0.645497425 & -3.082094841 & -1.107947302 \\ \mathrm{C} & -1.025382263 & -1.478265900 & -2.496775976 \\ \mathrm{H} & -1.958148198 & -1.956410650 & -2.825364964 \\ \mathrm{H} & -0.530485687 & -1.044581184 & -3.378596785 \\ \mathrm{C} & -1.879696152 & -1.188750477 & 1.507212954 \\ \mathrm{H} & -2.476883172 & -0.276570473 & 1.278522873 \\ \mathrm{C} & -1.919490377 & -1.361710203 & 3.025532365 \\ \mathrm{H} & -1.385825477 & -2.281368350 & 3.309527153 \\ \mathrm{H} & -1.424324218 & -0.521300938 & 3.531748164 \\ \mathrm{H} & -2.948019895 & -1.433621359 & 3.407192815 \\ \mathrm{C} & -2.617808698 & -2.359834662 & 0.854681340 \\ \mathrm{H} & -3.649561032 & -2.442618876 & 1.227098380 \\ \mathrm{H} & -2.661443453 & -2.253509850 & -0.236392959 \\ \mathrm{H} & -2.098697623 & -3.303293482 & 1.083074526 \\ \mathrm{O} & -0.564214159 & -1.071638472 & 1.089267927 \\ \mathrm{C} & -2.563910376 & 1.477904515 & -0.706789586 \\ \mathrm{H} & -2.903406580 & 2.340496446 & -1.298629449 \\ \mathrm{H} & -3.359865488 & 1.286175046 & 0.027329329\end{array}$

\section{$\mathbf{T S}_{\mathbf{C , D}}$}

$\begin{array}{lccc}G^{\circ}{ }_{\text {solv }} & -2756.033762 & & \\ \mathrm{Fe} & 0.355506590 & -0.062973930 & -0.426380349 \\ \mathrm{P} & 2.069548280 & -0.126427644 & 1.037367043 \\ \mathrm{O} & 2.145625829 & 0.853874376 & -2.485634731 \\ \mathrm{~N} & -1.203779566 & -0.466259097 & -1.497491137 \\ \mathrm{~N} & 0.777548221 & -1.949057865 & -0.727646245 \\ \mathrm{C} & 1.751269930 & -2.530263667 & -0.034139484 \\ \mathrm{H} & 1.900889045 & -3.611979166 & -0.168132727 \\ \mathrm{C} & 2.568921579 & -1.823939847 & 0.834322039 \\ \mathrm{H} & 3.398942709 & -2.292506155 & 1.361758078 \\ \mathrm{C} & 1.427220299 & 0.490155894 & -1.639496593 \\ \mathrm{C} & 1.728161141 & 0.177495248 & 2.814615670 \\ \mathrm{H} & 2.597067956 & -0.117844915 & 3.417259137\end{array}$

$\mathrm{H}$

$\mathrm{H}$

$\mathrm{P}$

C

$\mathrm{H}$

$\mathrm{H}$

$\mathrm{H}$

C

$\mathrm{H}$

$\mathrm{H}$

$\mathrm{H}$

C

$\mathrm{H}$

$\mathrm{H}$

C

$\mathrm{H}$

$\mathrm{H}$

$\mathrm{H}$

C

C

$\mathrm{H}$

$\mathrm{H}$

$\mathrm{H}$

C

$\mathrm{H}$

$\mathrm{H}$

$\mathrm{H}$

$\mathrm{O}$

C

C

$\mathrm{H}$

$\mathrm{C}$

$\mathrm{C}$
$\mathrm{H}$

$\mathrm{H}$

$\mathrm{H}$

D

$G^{\circ}$ solv -2756.066459

$\mathrm{Fe}$

$\mathrm{P}$

$\mathrm{O}$

$\mathrm{N}$

$\mathrm{N}$

$\mathrm{N}$

C

$\mathrm{H}$
1.530357490

0.854799712

3.526483840

3.225900415

4.301830096

3.949831259

$-0.598169288$

$-0.081780046$

$-0.745404984$

0.944355521

$-0.109662378$

$-0.711503889$

$-0.871200703$

0.243883210

$-1.513276172$

$-0.240379046$

0.202831155

$-0.861306142$

$-1.110966607$

$-2.106240992$

$-0.636075091$

$-2.252801499$

$-3.076263546$

$-2.941311531$

$-2.754012138$

$-4.146175963$

$-2.779096685$

$-2.481882574$

$-3.872330261$

$-2.347373533$

$-0.977396565$

$-2.327567180$

$-2.510595763$

$-3.081736884$

$-2.396584895$

$-3.277571837$

$-2.721282890$
1.243831288

$-0.400477448$

0.961216007

2.013869769

0.745760956

0.806939080

1.942656990

3.292089349

4.160023468

3.599154391

2.941428119

2.835168116

2.143864965

3.352300486

3.584227820

$-2.718411014$

$-3.465600309$

$-3.280324083$

$-1.736960617$

$-2.165934164$

$-1.554078251$

$-0.824773464$

0.090164304

$-0.227924540$

1.133055079

0.028876026

$-2.242308576$

$-2.771754626$

$-2.270526640$

$-2.783486586$

$-0.647076792$

1.551441552

2.125895963

1.861507754

0.062484815

$-0.241593159$

$-0.411333660$
2.983900711

3.132745592

0.793845652

0.889079719

1.540186396

$-0.204959915$

$-0.223547457$

$-1.344393402$

$-1.243379466$

$-1.106036416$

$-2.382692913$

1.369723376

2.202851099

1.528262794

1.350537123

$-1.418828040$

$-2.099471126$

$-0.699528650$

$-2.202866603$

$-2.401453945$

$-3.182691065$

1.302725043

2.185000574

3.230249336

2.112713787

1.953766579

1.234672336

2.151974490

1.160496735

0.385925797

1.255813009

$-0.801601338$

$-1.720310569$

$-0.067818647$

$-1.117330525$

$-1.705528246$

0.015934771
0.148633654
$-0.251061472$
0.310878905
2.154992393
0.250646421
$-0.672525640$
1.258966662
$-2.761686282$
1.168505753
$-1.446118954$
$-0.352943686$
1.452240889
0.908311533
0.666934189
1.855194706
2.170666020
1.073849787
1.857157710
2.559573425
1.539643952
2.774569642 


\begin{tabular}{|c|c|c|c|}
\hline $\mathrm{C}$ & 2.996128748 & 0.922009239 & 351 \\
\hline $\mathrm{H}$ & 4.031757433 & 1.261160620 & 0.753135745 \\
\hline & 0.802247357 & -1.750997700 & 6521 \\
\hline C & 2.260270598 & 1.492743534 & -2.026610537 \\
\hline $\mathrm{H}$ & 3.310839200 & 1.674117099 & -2.289656599 \\
\hline 1 & 1.724228290 & 1.135597977 & -2.916244976 \\
\hline $\mathrm{H}$ & 1.808209259 & 2.433494161 & -1.696949224 \\
\hline $\mathrm{C}$ & 3.204942413 & -1.076434886 & -1.385282928 \\
\hline $\mathrm{H}$ & 2.768768113 & -1.433068718 & -2.327837600 \\
\hline $\mathrm{H}$ & 4.215840745 & -0.699151871 & -1.588388760 \\
\hline $\mathrm{H}$ & 3.281210365 & -1.920212788 & -0.690029792 \\
\hline$P$ & -1.117048081 & -1.261214771 & -1.223172488 \\
\hline $\mathrm{C}$ & -0.681301759 & -2.960604164 & -1.744958010 \\
\hline $\mathrm{H}$ & -1.403413165 & -3.346027587 & -2.475442195 \\
\hline $\mathrm{H}$ & 0.321749942 & -2.969028189 & -2.189719507 \\
\hline $\mathrm{H}$ & -0.675035840 & -3.625770885 & -0.8725 \\
\hline $\mathrm{C}$ & -1.565187931 & -0.471659355 & -2.811521793 \\
\hline $\mathrm{H}$ & -1.913277979 & 0.554710602 & -2.64 \\
\hline $\mathrm{H}$ & -0.68028 & 2295 & 004 \\
\hline $\mathrm{H}$ & -2.356111959 & -1.039912343 & -3.317686531 \\
\hline $\mathrm{C}$ & -0.012428917 & 0.829711402 & 2.960274910 \\
\hline $\mathrm{H}$ & 0.503205511 & 0.816636660 & 2423 \\
\hline $\mathrm{H}$ & -0.544756651 & 1.798315788 & 2.883383646 \\
\hline $\mathrm{C}$ & -1.031498499 & -0.292606282 & 2.838056016 \\
\hline $\mathrm{H}$ & -1.890455331 & -0.107719093 & 3.514070527 \\
\hline $\mathrm{H}$ & -0.565343275 & -1.246911031 & 3.184950954 \\
\hline $\mathrm{C}$ & -1.357730584 & 2.526719735 & -0.532117093 \\
\hline $\mathrm{C}$ & -1.181441973 & 3.749689713 & -1.371689301 \\
\hline $\mathrm{H}$ & -1.008955707 & 4.609828389 & -0.710897669 \\
\hline $\mathrm{H}$ & -0.331882961 & 3.644967118 & -2.052 \\
\hline $\mathrm{H}$ & -2.097206295 & 3.965221638 & -1.935103106 \\
\hline $\mathrm{C}$ & -2.639127106 & 2.402509087 & 0.217887661 \\
\hline $\mathrm{H}$ & -3.449134954 & 2.243283299 & -0.508824227 \\
\hline $\mathrm{H}$ & -2.591974069 & 1.560917518 & 0.917131595 \\
\hline $\mathrm{H}$ & -2.867061724 & 3.347045317 & 0.727924227 \\
\hline $\mathrm{O}$ & -0.465296984 & 1.680460183 & -0.494676911 \\
\hline $\mathrm{C}$ & -2.702433364 & -1.459203645 & -0.293280640 \\
\hline $\mathrm{H}$ & -3.242334993 & -2.362369485 & -0.609247948 \\
\hline $\mathrm{H}$ & -3.331486834 & -0.587832711 & -0.526714562 \\
\hline $\mathrm{C}$ & -2.337360732 & -1.459427757 & 1.188130540 \\
\hline $\mathrm{H}$ & -1.890191579 & -2.448740578 & 1.456528744 \\
\hline 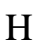 & -3.259288176 & -1.380296067 & 1.798732843 \\
\hline
\end{tabular}

$\mathbf{E}$

$G_{\text {solv }}^{\circ}-2563.013930$

$\begin{array}{llll}\mathrm{Fe} & 0.017575655 & 0.340741157 & 0.086853469\end{array}$

$\begin{array}{llll}\mathrm{P} & 1.795546953 & -0.994554476 & -0.259313821\end{array}$
0.179033131

$-1.158959348$

1.322759752

2.626361224

$\mathrm{H} \quad 3.313484060$

$\mathrm{C}$

3.108534701

$\mathrm{H}$

C

$\mathrm{C}$

$\mathrm{H}$

$\mathrm{H}$

$\mathrm{H}$

C

$\mathrm{H}$

$\mathrm{H}$

$\mathrm{H}$

$\mathrm{P}$

$\mathrm{P}$

$\mathrm{H}$

$\mathrm{H}$

$\mathrm{H}$

$\mathrm{H}$

C

$\mathrm{H}$

$\mathrm{H}$

$\mathrm{H}$

$\mathrm{C}$

4.170076317

0.131709168

1.930855935

2.953564598

1.236474613

1.685133305

2.173860197

1.355533932

3.104547832

2.283765512

$-1.715817272$

$-2.485222328$

$-3.401234485$

$-1.781930645$

$-2.731429996$

$-1.713564591$

$-1.296684892$

$-1.104715590$

$-2.737189636$

0.783808255

1.286435195

0.914527900

$-0.697887296$

$-1.248949427$

$-0.877271139$

$-2.984237357$

$-3.999203856$

$-2.911883079$

$-2.604208282$

$-2.959795724$

$-3.105092651$

$\mathrm{H}$

F

$G^{\circ}{ }_{\text {solv }}-2757.275068$

$\mathrm{Fe} \quad-0.601441636$

P $\quad-0.494437289$

O $\quad-2.946658946$

$\mathrm{N} \quad 0.024220139$

$\mathrm{N}$

0.810657053

C

1.192218207

H 1.974438878
$-0.203012985$

1.675014002

1.773384808

1.502418407

2.352975869

0.210089626

$-0.021566956$

$-0.013876348$

$-1.840017961$

$-2.209524431$

$-2.687795977$

$-1.132466311$

$-2.371936147$

$-3.104300526$

$-2.875498391$

$-1.986344704$

$-1.025863629$

$-1.774278811$

$-2.315266725$

$-2.473392671$

$-0.988526438$

$-2.414714497$

$-2.087583324$

$-3.238950852$

$-2.778531381$

3.069639390

3.900610721

3.238320067

3.022941730

3.780782231

3.255336799

0.146559619

$-0.160445478$

0.117955298

1.526215725

1.658892050

2.309390444
2.909871068

$-0.401499460$

$-0.030370979$

$-0.166398438$

$-0.280657254$

$-0.174864085$

$-0.247796330$

1.754233423

$-1.886064653$

$-2.037169475$

$-1.937429856$

$-2.686592898$

0.886592617

0.873992224

0.595837591

1.906344270

$-0.191212149$

1.289002048

1.021180283

1.758510625

2.013541727

$-1.378541903$

$-2.337721954$

$-0.987927409$

$-1.537701861$

$-0.409280505$

0.112100585

$-1.494362726$

$-0.095483288$

$-0.679157247$

0.974092811

$-0.839548860$

$-0.554845531$

$-1.936085809$

$-0.327372113$

0.715355865

$-0.923329213$

0.022931176 2.045394874

0.840414383

$-1.593001979$

0.737431018

2.021063987

2.372682752
$-0.457478346$

0.559311041

$-1.906909765$

$-1.116562328$

$-1.567911559$

$-1.477049311$

$-2.163976383$ 


\begin{tabular}{|c|c|c|c|}
\hline 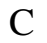 & 655 & 24 & 02 \\
\hline $\mathrm{H}$ & 0.945882118 & 3.915654081 & 35575 \\
\hline 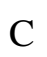 & -1.997652132 & 0.538419631 & -1.289553218 \\
\hline & 0.183874379 & 2.206904083 & 2.260064176 \\
\hline & 0.406130223 & 3.261043187 & 2.471976000 \\
\hline H & -0.545383165 & 1.844280595 & 2.995227607 \\
\hline & 1.105278682 & 1.620784637 & 2.350875295 \\
\hline & -2.011919719 & 3.060241546 & 0.708806191 \\
\hline $\mathrm{H}$ & -2.734072649 & 2.549513918 & 1.360402358 \\
\hline & -1.780583841 & 4.043760543 & 1.137050129 \\
\hline $\mathrm{H}$ & -2.467262983 & 3.202445427 & -0.277615765 \\
\hline & -1.786011782 & -1.219092458 & 0.952810593 \\
\hline$C$ & -3.594821287 & -1.341092722 & 0.726306278 \\
\hline $\mathrm{H}$ & -4.028508803 & -2.063832954 & 1.428310219 \\
\hline $\mathrm{H}$ & -4.060008571 & -0.360557289 & 0.886785740 \\
\hline $\mathrm{H}$ & -3.811905955 & -1.663239713 & -0.299595069 \\
\hline C & -1.607241827 & -1.052340705 & 4393 \\
\hline $\mathrm{H}$ & -0.545121529 & -0.975608099 & 3.023298227 \\
\hline $\mathrm{H}$ & -2.124114673 & -0.144110199 & 341308 \\
\hline $\mathrm{H}$ & -2.044332736 & -1.9 & 198 \\
\hline C & 1.488203913 & -0.217679438 & -2.432364918 \\
\hline $\mathrm{H}$ & 1.632261227 & 0.173569226 & -3.452017567 \\
\hline $\mathrm{H}$ & 2.493227404 & -0.454811920 & 9642 \\
\hline $\mathrm{C}$ & 0.635967604 & -1.477054630 & -2.432410825 \\
\hline $\mathrm{H}$ & 1.248810459 & -2.364584118 & -2.670808049 \\
\hline $\mathrm{H}$ & -0.146955439 & -1.413044365 & -3.217014894 \\
\hline $\mathrm{C}$ & -1.148373464 & -2.899923207 & 43683 \\
\hline $\mathrm{H}$ & -1.899099669 & -3.677544037 & 0.732626163 \\
\hline $\mathrm{H}$ & -0.284354910 & -3.080362092 & 1.196098468 \\
\hline $\mathrm{C}$ & -0.693384966 & -2.839056335 & -0.910537194 \\
\hline $\mathrm{H}$ & -1.569331997 & -2.916348345 & 404 \\
\hline $\mathrm{H}$ & -0.046357697 & -3.702325666 & 6144 \\
\hline $\mathrm{C}$ & 3.646443898 & -0.766299733 & 0.624356016 \\
\hline $\mathrm{H}$ & 3.401096777 & -1.553325798 & -0.111890019 \\
\hline $\mathrm{C}$ & 4.276891697 & -1.403861669 & 1.840120679 \\
\hline $\mathrm{H}$ & 5.215560711 & -1.902851176 & 1.572448708 \\
\hline $\mathrm{H}$ & 4.499093351 & -0.639471896 & 2.597393548 \\
\hline $\mathrm{H}$ & 3.607017822 & -2.148048418 & 2.286690936 \\
\hline $\mathrm{C}$ & 4.556660533 & 0.258009140 & -0.021998081 \\
\hline- & 4.062969704 & 0.746195501 & -0.873170063 \\
\hline H & 4.827705982 & 1.035619736 & 0.705462833 \\
\hline $\mathrm{H}$ & 5.479233901 & -0.210015981 & -0.388119431 \\
\hline $\mathrm{O}$ & 2.430037967 & -0.149146892 & 1.057878921 \\
\hline & 1.925112494 & 0.117510563 & 0.267316272 \\
\hline
\end{tabular}

$\mathbf{T S}_{\mathbf{F}, \mathrm{G}}$

$G^{\circ}{ }_{\text {solv }} \quad-2757.251937$
$\mathrm{Fe}$
$-0.629369648$

0.533303604

$-2.606699617$

$-0.973740860$

0.758194780

1.817613496

2.595233859

2.059599870

2.564133715

$-1.787973759$

1.070398514

1.874445158

0.218948120

1.430890339

$-0.117344051$

$-1.071418387$

0.597082517

$-0.283626871$

$-2.043915146$

$-3.667855039$

$-4.259983383$

$-3.530856791$

$-4.212770586$

$-1.499158908$

$-0.524258922$

$-1.410165736$

$-2.229963834$

0.703768111

0.874664353

1.507969995

$-0.642117962$

$-0.597685986$

$-1.418689554$

$-2.414175096$

$-3.421029286$

$-1.682183909$

$-2.201646591$

$-3.071814335$

$-2.144599151$

3.487592196

3.271081182

2.258907914

2.025492988

2.422171922

1.369171327

4.697257435

5.575290631
$-0.073547714$

1.872870719

1.117422628

$-1.900150150$

$-0.503261541$

0.225539827

$-0.124635189$

1.415337925

2.231618100

0.674937778

2.611221383

3.337737269

3.133024479

1.845549461

3.347131229

3.656654691

4.176876027

3.110105420

$-0.076753873$

0.740671943

0.597532868

1.814490434

0.312871864

0.414041019

$-0.034232987$

1.505032411

0.076250037

$-1.881093852$

$-1.923679572$

$-2.452273143$

$-2.449958998$

$-3.552460780$

$-2.183582580$

$-1.878867651$

$-2.059486451$

$-2.307630120$

$-2.452731517$

$-2.214134480$

$-3.554671662$

$-0.834375248$

$-1.180746343$

$-1.188070780$

$-2.263338000$

$-0.900419643$

$-0.648393903$

$-1.630780769$

$-1.407455015$
$-0.404109257$

$-0.196466331$

$-2.118803289$

$-0.503045602$

$-1.715183254$

$-1.887945290$

$-2.580649761$

$-1.101326315$

$-1.633387014$

$-1.413342694$

1.389141127

1.214536242

1.842914069

2.083388906

$-1.065438790$

$-0.619942466$

$-0.994337143$

$-2.122739706$

1.319849235

1.155006198

2.066997159

0.977861357

0.304840703

2.989661059

3.212908457

3.048017588

3.735773897

$-2.212963909$

$-3.297126249$

$-1.720591181$

$-1.809750731$

$-1.783736918$

$-2.556333558$

1.437590136

1.835682644

2.137887733

0.046203542

$-0.602372019$

0.088568543

0.747618363

$-0.297785272$

1.584771828

1.550810450

2.634905748

1.218551707

1.222805282

0.602998153 
4.517378425

3.749162033

2.878105436

G

$G_{\text {solv }}^{\circ}-2757.280887$

$\mathrm{Fe} \quad-0.091230272$

P $\quad 1.434511488$

O $\quad-0.958792931$

N -1.053651245

$\mathrm{N} \quad 1.406062454$

C 2.619549638

H $\quad 3.412620469$

C $\quad-0.609974921$

C $\quad 1.806105362$

$\mathrm{H} \quad 2.776282335$

H 1.027568109

$\mathrm{H} \quad 1.815745463$

C $\quad 1.503849901$

$\mathrm{H} \quad 0.596523066$

$\mathrm{H} \quad 2.381341431$

$\mathrm{H} \quad 1.546699166$

P $\quad-1.961572885$

C -2.995785635

$\mathrm{H} \quad-3.909477451$

$\mathrm{H} \quad-2.431406594$

$\mathrm{H} \quad-3.279926983$

C $\quad-2.007290048$

$\mathrm{H} \quad-1.379827788$

$\mathrm{H} \quad-1.627402591$

H $\quad-3.038235689$

C 1.014859457

$\mathrm{H} \quad 1.521153684$

$\mathrm{H} \quad 1.345010401$

C -0.500308535

$\mathrm{H} \quad-0.844075956$

H $\quad-0.796961649$

C -2.991241103

$\mathrm{H} \quad-4.062188432$

H $\quad-2.806899382$

C -2.490984115

$\mathrm{H} \quad-2.828559300$

H $\quad-2.974109672$

C 0.839081750

H 0.553932245

C $\quad 0.041000507$
$-2.714605139$

0.527619317

1.041530011

2.261693545

1.184754908

0.758120208

$-0.217105554$

$-0.179565803$

$-1.533281289$

$-2.307734691$

1.273283796

0.405038937

0.052709856

0.445414119

$-1.432437002$

$-1.566716565$

$-2.044950487$

$-2.142712470$

$-0.547912807$

$-3.312895228$

$-3.811629677$

$-3.799863903$

$-3.429511050$

$-0.418145808$

$-1.915078039$

$-1.847779250$

$-2.805383184$

$-2.032108477$

$-0.207542811$

0.637412354

$-1.117855537$

$-0.038469918$

1.384462872

1.175946557

2.373740440

1.351211930

2.254397847

0.485425007

0.935403408

0.696354513

1.843067705

1.129685713

0.264294334

2.020252096

2.419972566

2.735626584

3.296947196
0.341446649

$-0.598607812$

2.116945639

1.289193732

1.482875198

1.307222124

1.956992052

1.423759570

$-2.386160151$

$-2.571408087$

$-2.900790381$

$-2.785961791$

$-0.167071009$

$-0.531052574$

$-0.610513777$

0.922265620

$-0.834219453$

$-0.616901846$

$-1.220805209$

$-0.923583398$

0.435294199

$-2.647745689$

$-2.947742659$

$-3.127290700$

$-2.984423474$

2.505720913

3.457830982

2.157136799

2.621634279

3.163378355

3.262209536

$-0.115665964$

$-0.173040341$

$-0.708477757$

1.311697259

1.936428335

1.761364388

$-0.909090456$

0.114375021

$-1.872113106$
0.256359192

$\mathrm{H} \quad 0.280978730$

$\mathrm{H} \quad-1.037806016$

C 2.333375419

$\mathrm{H} \quad 2.929222842$

$\mathrm{H}$

2.663473964

$\mathrm{H}$

2.570484652

$\mathrm{O}$

0.540870082

2.985804426

$\mathrm{H} \quad 3.541040770$

H 3.664600774

$\mathbf{T S}_{\mathbf{G}, \mathbf{H}}$

$G_{\text {solv }}^{\circ}-2757.242395$

$\mathrm{Fe}$

$\mathrm{P}$

$\mathrm{O}$

$\mathrm{N}$

$\mathrm{N}$

$\mathrm{C}$

C

C

$\mathrm{H}$

$\mathrm{H}$

$\mathrm{H}$

C

C

$\mathrm{H}$

$\mathrm{H}$

$\mathrm{H}$

$\mathrm{P}$

(

C

$\mathrm{H}$

$\mathrm{H}$

$\mathrm{H}$

C

C

$\mathrm{H}$

$\mathrm{H}$

$\mathrm{H}$

C

$\mathrm{H}$

$\mathrm{H}$

C

$\mathrm{H}$

$\mathrm{H}$

$\mathrm{C}$

C

$\mathrm{H}$

$\mathrm{H}$

C
$-0.327636705$

0.982340721

$-1.976447026$

$-1.027628641$

1.081927508

$-1.320091349$

1.378275817

2.273813016

0.529059468

1.525055049

0.659527295

$-0.276380476$

1.475614976

0.557318863

$-1.938648228$

$-3.295799289$

$-4.030346583$

$-2.887503449$

$-3.802848743$

$-1.571057835$

$-0.779294696$

$-1.232274184$

$-2.472096356$

0.830851578

1.138979055

1.418900309

$-0.650178903$

$-0.852913936$

$-1.219866295$

$-2.747450245$

$-3.821059145$

$-2.268711462$

$-2.442462790$
4.366477854

3.035476474

3.146342166

2.691572699

2.150156988

2.358522583

3.761646484

1.078775363

$-0.856893809$

$-0.278253027$

$-1.653008150$
$-1.732227783$

$-2.914966976$

$-1.725086706$

$-1.086495626$

$-0.338120524$

$-2.083715271$

$-0.992308722$

$-1.112160241$

0.185341465

$-0.569910424$

0.521391097
$-0.028564329$

1.794762029

1.085278274

$-1.860841853$

$-0.748162733$

0.629039023

2.722995255

3.343115964

3.380822452

2.039846196

3.165426705

3.671008232

3.899147133

2.764514486

0.300628052

1.471564474

1.488037391

2.481576868

1.174686877

0.687992591

0.029525803

1.727628339

0.555397897

$-2.122426402$

$-2.284479494$

$-2.825872445$

$-2.395029876$

$-3.482060447$

$-1.921855434$

$-1.359710405$

$-1.283627258$

$-1.939401687$

$-1.997047970$ 


$\begin{array}{lrrr}\mathrm{H} & -3.075917861 & -1.516236347 & -0.983423121 \\ \mathrm{H} & -2.743571455 & -3.063250352 & -0.186941686 \\ \mathrm{C} & 2.184385083 & -1.104765745 & 1.285184431 \\ \mathrm{C} & 2.225909140 & -2.621656383 & 1.347428593 \\ \mathrm{H} & 3.163058341 & -3.033172785 & 0.953055131 \\ \mathrm{H} & 2.145785503 & -2.922164707 & 2.403939268 \\ \mathrm{H} & 1.376445625 & -3.051717357 & 0.808689746 \\ \mathrm{C} & 3.328231579 & -0.440302322 & 2.026414783 \\ \mathrm{H} & 3.352540658 & 0.641779505 & 1.857941792 \\ \mathrm{H} & 3.184019253 & -0.606937533 & 3.104812706 \\ \mathrm{H} & 4.298459326 & -0.869312742 & 1.747727872 \\ \mathrm{O} & 1.028106213 & -0.532096678 & 1.335931508 \\ \mathrm{C} & 2.575833819 & 1.069932044 & -0.971853650 \\ \mathrm{H} & 3.414273704 & 1.265952045 & -0.292378269 \\ \mathrm{H} & 2.816917343 & 1.556520177 & -1.927193695 \\ \mathrm{C} & 2.357871060 & -0.412306030 & -1.209237077 \\ \mathrm{H} & 2.621700358 & -0.917716881 & -0.037209342 \\ \mathrm{H} & 3.157575429 & -0.914583104 & -1.778867360\end{array}$

H

$G_{\text {solv }}^{\circ}-2757.275574$

$\mathrm{Fe} \quad-0.725638642$

P 0.021344166

O $\quad-2.716374433$

$\mathrm{N} \quad-0.694749571$

$\mathrm{N} \quad 0.913796863$

C $\quad-1.942450933$

C $\quad 0.983617081$

$\mathrm{H} \quad 1.619862868$

$\mathrm{H} \quad 0.297362851$

H 1.602384334

C $\quad-0.994940421$

$\mathrm{H} \quad-1.714763585$

H $\quad-0.376469936$

$\mathrm{H} \quad-1.553330058$

P $\quad-2.222857168$

C $\quad-3.904387564$

$\mathrm{H} \quad-4.526346884$

$\mathrm{H} \quad-3.849328407$

H $\quad-4.377113518$

C $\quad-1.799913750$

$\mathrm{H} \quad-0.785901691$

H $\quad-1.831690849$

H $\quad-2.509279149$

C 1.303192915

$\mathrm{H} \quad 1.794554803$

H 2.034461659
$-0.107584611$

1.957870190

0.696429936

$-2.022619916$

$-0.345602572$

0.362423406

2.279598342

3.166668922

2.443043403

1.403768576

3.464533985

3.509760680

4.370979602

3.428903423

$-0.315240173$

0.376284031

0.165130859

1.462208736

$-0.069472654$

0.182898533

$-0.159736329$

1.276889430

$-0.244280300$

$-1.714021636$

$-1.815145037$

$-2.070436309$
$-0.439368964$

$-0.158344107$

$-2.351526950$

$-0.343867282$

$-1.285076580$

$-1.529691631$

1.366028369

1.249197018

2.205740174

1.596605539

$-0.326633704$

0.500533326

$-0.308398126$

$-1.269747696$

1.183590380

0.980709596

1.859609817

0.831818496

0.096723749

2.892136063

2.972368308

$-1.562216124$

$-2.548106942$

$-0.804463927$
3.132011014

3.612886620
C

$\mathrm{H}$

$\mathrm{H}$

C

C

$\mathrm{H}$

$\mathrm{H}$

C

$\mathrm{H}$

$\mathrm{H}$

C

C

$\mathrm{C}$

$\mathrm{H}$

$\mathrm{H}$

$\mathrm{H}$

C

$\mathrm{H}$

$\mathrm{H}$

$\mathrm{H}$

$\mathrm{O}$

C

$\mathrm{H}$

$\mathrm{H}$

C

$\mathrm{H}$

$\mathrm{H}$

\section{H2}

$G^{\circ}{ }_{\text {solv }} \quad-2757.276525$

Fe $\quad-0.860606352$

P $\quad-0.092596077$

O $\quad-2.766356531$

N $\quad-0.200661567$

$\mathrm{N} \quad 0.610179617$

C $\quad-1.989848662$

C 0.445108909

$\mathrm{H} \quad 1.178321700$

$\mathrm{H}$

$\mathrm{H}$

C

$\mathrm{H}$

$\mathrm{H}$

$\mathrm{H}$

$\mathrm{H}$

$\mathrm{P}$

C

$\mathrm{H}$

$\mathrm{H}$

$\mathrm{H}$
$-2.545998393$

$-3.621122968$

$-2.446310147$

$-2.146338212$

$-2.394103752$

$-2.525582100$

$-2.700610078$

$-2.556855702$

$-3.793278292$

$-0.601820257$

$-1.646058761$

$-1.369505323$

$-1.679874997$

$-2.630194663$

0.731169841

1.510312372

0.657635889

1.005086722

$-0.827250956$

2.044832898

2.854429638

2.255009475

0.666607512

0.621871794

0.505066974
$-1.472787656$

$-1.355924322$

$-2.420864203$

1.253959449

1.441703182

2.093711381

$-0.059199324$

$-0.867897314$

0.023744919

1.047051902

0.234387160

$-0.828154515$

0.490189699

0.375994270

1.143529746

1.453562372

1.900173698

0.199834899

1.619930344

$-1.522597476$

$-1.380980574$

$-2.435014144$

$-1.609573112$

$-0.909977865$

-2.617219576

0.082337987

1.649881824

$-0.604726710$

1.908374284

$-1.617196159$

0.561392941

1.198965730

1.181038560

1.904343139

1.169537855

0.181791790

3.188611485

2.945748968

3.839100972

3.726790594

$-0.926691727$

$-1.344287111$

$-2.056843565$

$-0.432064837$

$-1.778020427$
0.716230632

$-1.815825834$

$-0.794580489$

$-1.854990089$

$-1.296004714$

2.781774099

3.075728256

2.383364703

1.022320200

1.437329341

1.724462229

0.077570855

0.645287543

$-0.226633545$

0.352190623

$-0.387665104$

$-1.206254136$
2.400724850 


$\begin{array}{lrrr}\mathrm{C} & -3.009288672 & -0.389065367 & 2.281065274 \\ \mathrm{H} & -2.170110849 & -0.255396138 & 2.972992965 \\ \mathrm{H} & -3.541108198 & 0.564851940 & 2.182993082 \\ \mathrm{H} & -3.697213777 & -1.135494782 & 2.699104093 \\ \mathrm{C} & 1.621030154 & -0.470412951 & -1.753227680 \\ \mathrm{H} & 2.354770351 & -0.421788722 & -2.583378198 \\ \mathrm{H} & 2.209095120 & -0.403524293 & -0.808473757 \\ \mathrm{C} & 0.894332004 & -1.790773901 & -1.736423312 \\ \mathrm{H} & 1.556884785 & -2.623640856 & -1.441331884 \\ \mathrm{H} & 0.507471351 & -2.032979508 & -2.746077379 \\ \mathrm{C} & -1.593854135 & -2.551899365 & 0.957549471 \\ \mathrm{H} & -2.323836089 & -3.336685169 & 1.196085593 \\ \mathrm{H} & -0.939904320 & -2.409638528 & 1.830571591 \\ \mathrm{C} & -0.757063748 & -2.858316080 & -0.274555491 \\ \mathrm{H} & -1.374894416 & -3.361819580 & -1.042982799 \\ \mathrm{H} & 0.052552189 & -3.566281869 & -0.023794444 \\ \mathrm{C} & 4.139463307 & -0.625994661 & 0.832250485 \\ \mathrm{C} & 3.994151007 & -2.071944728 & 0.472240550 \\ \mathrm{H} & 3.056722570 & -2.478485758 & 0.866525332 \\ \mathrm{H} & 4.059621975 & -2.231132739 & -0.610315780 \\ \mathrm{H} & 4.830492413 & -2.620653566 & 0.928164126 \\ \mathrm{C} & 5.059548669 & 0.192701203 & -0.016210427 \\ \mathrm{H} & 5.224479713 & 1.182180408 & 0.418741417 \\ \mathrm{H} & 6.016390931 & -0.326947849 & -0.151926972 \\ \mathrm{H} & 4.620770415 & 0.303867730 & -1.018042855 \\ \mathrm{O} & 3.548234914 & -0.145119655 & 1.793576334 \\ \mathrm{C} & 1.431107238 & 2.193677726 & -0.165449032 \\ \mathrm{H} & 2.266352109 & 1.593030322 & 0.223394751 \\ \mathrm{H} & 1.655201457 & 3.251249529 & 0.036670235 \\ \mathrm{C} & 1.167675929 & 1.888639248 & -1.645122223 \\ \mathrm{H} & 2.103348234 & 2.017829105 & -2.222402520 \\ \mathrm{H} & 0.460417395 & 2.641383439 & -2.035052067\end{array}$

\section{$\mathbf{T S}_{\mathbf{H} 2, \mathrm{I}}$}

$G_{\text {solv }}^{\circ} \quad-2757.244563$

Fe $\quad-0.586032518$

P $\quad-0.381343655$

O $\quad-2.503244422$

$\mathrm{N} \quad 0.140259865$

$\mathrm{N} \quad 1.061298110$

C $\quad-1.725073894$

C $\quad-0.175068632$

$\mathrm{H} \quad 0.272727544$

H $\quad-1.149846821$

$\mathrm{H} \quad 0.478128893$

C $\quad-1.578842360$

H $\quad-2.588104894$
0.001726717

1.947400402

1.151366168

$-1.667957703$

0.551601172

0.724582081

1.977937628

2.932551843

1.870903529

1.155443320

3.300197408

2.974384685
$-0.507787673$

0.582831493

$-2.339393064$

$-0.699835107$

$-1.390360399$

$-1.575782626$

2.398315167

2.704401803

2.887798503

2.711508013

0.298937758

0.580602715
H

$\mathrm{H}$

$\mathrm{P}$

C

C $\quad-3.745109578$

$\mathrm{H} \quad-4.364391859$

$\mathrm{H}$

$\mathrm{H}$

C

$\mathrm{H}$

$\mathrm{H}$

$\mathrm{H}$

$\mathrm{H}$

C

$\mathrm{H}$

$\mathrm{H}$

C

$\mathrm{H}$

C

$\mathrm{H}$

$\mathrm{H}$

$\mathrm{H}$

$\mathrm{H}$

C

$\mathrm{H}$

$\mathrm{H}$

$\mathrm{H}$

$\mathrm{O}$

C

C

$\mathrm{H}$

$\mathrm{H}$

C

$\mathrm{H}$

$\mathrm{H}$

C

$\mathrm{H}$

$\mathrm{H}$

C

$\mathrm{H}$

$\mathrm{H}$

C

$\mathrm{H}$

I

$G^{\circ}{ }_{\text {solv }}-2757.274039$

Fe $\quad-0.186552821$

P $\quad 1.276028628$

O $\quad-1.295451978$

N -1.171366263

N 1.286579877
4.185352727

3.569782874

$-1.070501592$

$-1.386118483$

$-2.102418691$

$-0.448219029$

$-1.787552566$

$-0.610118492$

$-0.495607135$

0.340171148

$-1.384284439$

$-1.774312662$

$-2.586815226$

$-1.999334810$

$-0.568741064$

$-0.566435010$

$-2.065904075$

$-2.473624398$

$-2.622146036$

$-2.230193274$

0.030141605

0.012040264

$-0.526141776$

1.076490656

0.135894545

$-2.733215197$

$-3.519641017$

$-2.691081215$

1.951902632

2.067519235

2.462602022

2.592603049

2.251798412

3.690888585

$-2.934230319$

$-3.296365848$

$-3.712304769$

$-0.432556909$

$-0.262734055$
0.889197164

$-0.764290881$ 0.622879167

$-0.257777767$

0.295970700

$-0.374134612$

$-1.256357019$

2.295879327

2.959635568

2.255532720

2.700651095

$-1.581154272$

$-1.274757094$

$-2.622159186$

0.740781165

$-0.396413211$

1.001040316

1.271505374

0.143046699

1.852554852

0.210036949

1.007855838

$-0.649555458$

$-0.083523979$

1.606014157

0.813717168

0.935697075

1.727109126

$-1.447393700$

$-1.775215804$

$-2.194688391$

$-0.079357180$

0.619734732

$-0.112315489$

$-0.396305711$

$-1.260738210$

$-0.191852669$

$-1.547163381$

$-2.214219879$ $\begin{array}{cl}0.187906663 & -0.393860327 \\ 1.545169119 & 0.643101252 \\ 2.337024958 & -1.994528801 \\ -1.012485176 & -1.668856834 \\ -0.156304085 & -1.652662930\end{array}$ 


\begin{tabular}{|c|c|c|c|}
\hline$C$ & -0.826164968 & 2622 & -1 \\
\hline & 1.687313578 & 1.545062510 & 2.426652138 \\
\hline & 2.622935060 & 2.086613035 & 2.615974448 \\
\hline $\mathrm{H}$ & 0.872108888 & 2.049756305 & 2.961460314 \\
\hline & 1.772823372 & 0.525508727 & 2.816301042 \\
\hline $\mathrm{C}$ & 1.140300320 & 3.345559191 & 0.321008127 \\
\hline $\mathrm{H}$ & 0.177243396 & 3.719605150 & 0.691213360 \\
\hline $\mathrm{H}$ & 1.952389649 & 3.895069975 & 6805 \\
\hline $\mathrm{H}$ & 1.189370207 & 3.535787056 & -0.75 \\
\hline$P$ & -2.067183377 & 0.162297864 & 0.809238842 \\
\hline$C$ & -2.987703008 & 5994 & 160 \\
\hline $\mathrm{H}$ & -3.996482165 & 1.473443302 & 6650 \\
\hline $\mathrm{H}$ & -2.448106439 & 2.262379396 & 9493 \\
\hline $\mathrm{H}$ & -3.068931181 & 2.327054709 & 592 \\
\hline C & -2.162612662 & -0.723920864 & 768 \\
\hline $\mathrm{H}$ & -1.862999282 & -1.768302447 & 20137 \\
\hline $\mathrm{H}$ & -1.485601895 & -0.253678521 & 327 \\
\hline $\mathrm{H}$ & -3.188238896 & -0.6828 & 843 \\
\hline $\mathrm{C}$ & -0.210524162 & -1.853551515 & -2.33 \\
\hline $\mathrm{H}$ & 0.007798495 & -2.803532111 & -1.7 \\
\hline $\mathrm{H}$ & -0.533099087 & -2.179633378 & 30741 \\
\hline $\mathrm{C}$ & 1.523162399 & -1.853051401 & 1002 \\
\hline $\mathrm{H}$ & 2.202593426 & -0.990744558 & 7626 \\
\hline $\mathrm{C}$ & 2.311585069 & -2.841582913 & 6718 \\
\hline $\mathrm{H}$ & 1.705754898 & -3.740886373 & 9873 \\
\hline $\mathrm{H}$ & 2.579908187 & -2.402 & -0.6 \\
\hline $\mathrm{H}$ & 3.241574735 & -3.158476841 & 6411 \\
\hline $\mathrm{C}$ & 1.267762842 & -2.482126662 & 2550 \\
\hline $\mathrm{H}$ & 2.199817643 & -2.794352330 & 4218 \\
\hline $\mathrm{H}$ & 0.749989977 & -1.777382441 & 4523 \\
\hline $\mathrm{H}$ & 0.627320959 & -3.370625016 & 94954 \\
\hline $\mathrm{O}$ & 0.327025173 & -1.469833371 & 58151 \\
\hline $\mathrm{C}$ & -3.168332264 & -0.787797913 & -0.3 \\
\hline $\mathrm{H}$ & -3.616692818 & -0.056512872 & -1.02 \\
\hline $\mathrm{H}$ & -3.979753438 & -1.290798219 & 0.213023552 \\
\hline $\mathrm{C}$ & 2.495148502 & 0.664901175 & -1.664989696 \\
\hline $\mathrm{H}$ & 3.324831234 & 0.130614006 & -2.14 \\
\hline $\mathrm{H}$ & 2.273902611 & 1.555189889 & -2.27 \\
\hline $\mathrm{C}$ & 2.847915720 & 1.096658787 & -0.244456523 \\
\hline $\mathrm{H}$ & 3.324783412 & 0.273989353 & 0.303592253 \\
\hline $\mathrm{H}$ & 3.548511816 & 1.942231383 & -0.251503077 \\
\hline $\mathrm{C}$ & -2.273729105 & -1.750876931 & -1.102739123 \\
\hline $\mathrm{H}$ & -2.867957711 & -2.254050908 & -1.892535575 \\
\hline $\mathrm{H}$ & -1.942654905 & -2.565821277 & -0.417889361 \\
\hline $\mathrm{C}$ & 1.091569197 & -1.141283235 & -2.439862677 \\
\hline$H$ & 1.861324801 & -1.467275794 & -3.151259710 \\
\hline
\end{tabular}

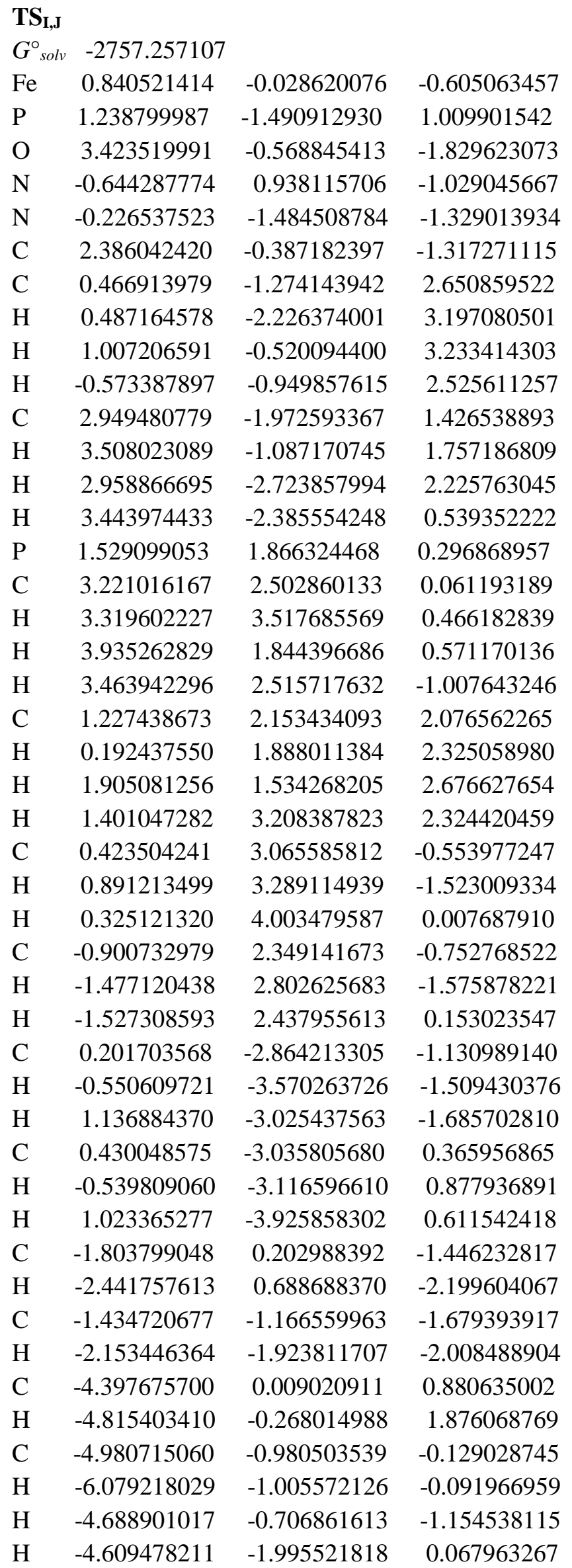




$\begin{array}{lrrr}\mathrm{C} & -4.892351884 & 1.420958962 & 0.570401607 \\ \mathrm{H} & -4.500256922 & 2.137662161 & 1.304349025 \\ \mathrm{H} & -4.543242439 & 1.735707695 & -0.425568291 \\ \mathrm{H} & -5.989960644 & 1.487865467 & 0.580478708 \\ \mathrm{O} & -3.007889987 & -0.050044644 & 0.925597960 \\ \mathrm{H} & -2.487516597 & 0.090174822 & -0.405292938\end{array}$

J

$G^{\circ}{ }_{\text {solv }}-2757.302312$

$\mathrm{Fe} \quad-0.590591581$

P $\quad-0.984407947$

O $\quad-3.117595982$

N $\quad 0.430260389$

N 0.695905019

C $\quad-2.098119528$

C $\quad-0.892445704$

$\mathrm{H} \quad-0.879104558$

H $\quad-1.769011635$

H $\quad 0.012225888$

C $\quad-2.528748712$

H $\quad-3.396332208$

$\mathrm{H} \quad-2.551606825$

H $\quad-2.603520399$

P $\quad-1.217098687$

C $\quad-2.943745598$

$\mathrm{H} \quad-3.114236347$

$\mathrm{H} \quad-3.638518707$

$\mathrm{H} \quad-3.151443202$

C -0.953330711

$\mathrm{H} \quad 0.074606482$

$\mathrm{H} \quad-1.644001198$

$\mathrm{H} \quad-1.135550912$

C $\quad-0.201945698$

H $\quad-0.721982959$

H 0.713737266

C 0.144346739

$\mathrm{H} \quad-0.703191155$

$\mathrm{H} \quad 1.009700227$

C $\quad 0.718554430$

$\mathrm{H} \quad 1.713034805$

H $\quad-0.001793804$

C $\quad 0.348186603$

H $\quad 1.203757272$

H 0.032765705

C 1.346232679

H 1.927999256

C 1.495074348
0.022164311

1.818960590

0.147811380

$-1.316001894$

1.118406993

0.101544221

1.899837782

2.945970402

1.404264875

1.397034695

2.757955032

2.144268251

3.687303499

3.002505154

$-1.636671406$

$-2.241462580$

$-3.109534941$

$-1.439562204$

$-2.524523814$

$-1.709241075$

$-1.419424973$

$-1.024129907$

$-2.728207767$

$-3.048754626$

$-4.008619480$

$-3.073338905$

$-3.008331501$

$-3.334896757$

2.575072243

2.962315406

3.009398878

2.973265386

2.818985505

4.022551299

$-0.872970452$

$-1.560947173$

0.501020218
$-2.741522930$
$-0.546809911$

0.693869248

$-1.950199596$

$-1.406202797$

$-1.383580977$

$-1.361023818$

2.522022621

2.855730472

2.956832363

2.881366824

0.384612819

0.658412250

0.968127136

$-0.682133620$

0.786814919

0.656330107

1.305516384

0.937343695

$-0.383198657$

2.599084100

2.844607484

3.104904142

2.966025061

0.151554097

0.275711020

0.760157440

$-1.297127491$

$-1.952412092$

$-1.632794357$

$-1.287498386$

$-1.561323275$

$-2.002250534$

0.132376966

0.805497585

0.212594509

$-2.296353369$

$-2.911937965$

$-2.288601076$
2.205757583

H 1.644271296

$\mathbf{K}$

$G^{\circ}{ }_{\text {solv }}-2563.036466$

$\mathrm{Fe} \quad-0.000540074$

P 1.744035019

O $\quad-0.027799593$

$\mathrm{N} \quad-1.238262867$

$\mathrm{N} \quad 1.209914984$

C $\quad-0.015791377$

C $\quad 1.827714622$

$\mathrm{H} \quad 2.867429258$

$\mathrm{H} \quad 1.239025247$

$\mathrm{H} \quad 1.422950293$

C 2.519728643

$\mathrm{H} \quad 1.811565137$

$\mathrm{H} \quad 3.433805975$

H 2.767865009

P $\quad-1.723065227$

C -2.452325908

$\mathrm{H} \quad-3.353914455$

$\mathrm{H} \quad-1.716874896$

H $\quad-2.712222042$

C -1.799619019

$\mathrm{H} \quad-1.429360260$

$\mathrm{H} \quad-1.177855971$

H $\quad-2.833427921$

C -3.049009616

$\mathrm{H} \quad-4.044283693$

H $\quad-3.025219854$

C -2.681866065

$\mathrm{H} \quad-2.980133709$

$\mathrm{H} \quad-3.210660073$

C 2.659588036

H 3.158945411
1.057138623

$-0.149144853$

$-0.128021851$

0.927254851

0.749987495

0.932765777

1.919054864

$-1.531985757$

$-2.296746616$

$-1.585155487$

$-1.771251023$

0.134158610

0.130737469

$-2.901227296$

1.220535969

2.161619428

0.295534274

0.055015549

$-0.648138152$

0.756580980

0.607947759

1.304042917

$-0.316242275$

0.352799368

1.613784177

0.819011036

0.352026003

$-0.970052728$

0.139216789

$-0.226830428$

$-0.072593896$

1.724627618

1.735357628

0.080331352

$-2.301444525$

$-2.622761855$

$-3.165036479$

$-1.945275068$

$-1.798373251$

$-2.512830605$

$-2.332611456$

$-1.049767369$

$-0.988806018$

$-1.905301648$

$-2.454229707$

$-2.615450377$

$-1.198823763$

$-2.256212078$

$-1.836684742$

$-3.118487752$

$-2.599063340$

0.210502620

$-0.144345649$

0.279251873

1.553293767

1.578452309

2.377865239

1.588443265

2.406339939
3.000817269

$-0.243242992$

$-0.281749665$

1.831753323

$-1.483936945$

$-1.632150290$

$-1.151782662$

$-2.438011891$

1.214549296

1.653507926

0.925793756

1.976959402

$-0.257373341$

1.153280821

0.852979183

1.553039900

1.951365702

$-1.579469874$

$-2.521809606$

$-1.310382979$

$-1.720543745$

$-0.741335045$

$-0.440101684$

$-1.838439653$

$-0.130273390$

0.932324216

$-0.632635809$

$-0.209466832$

$-0.751467863$ 


$\begin{array}{lrrr}\mathrm{H} & 2.990944197 & 1.650555598 & 0.841685239 \\ \mathrm{C} & 3.030622759 & 0.234730526 & -0.792433077 \\ \mathrm{H} & 2.968481687 & 0.268477811 & -1.889742202 \\ \mathrm{H} & 4.042207366 & -0.092172622 & -0.515225992 \\ \mathrm{C} & -0.713545592 & 2.962223922 & -0.404836014 \\ \mathrm{H} & -1.347250488 & 3.839753368 & -0.540013370 \\ \mathrm{C} & 0.667843464 & 2.969273971 & -0.426700190 \\ \mathrm{H} & 1.288271059 & 3.853096673 & -0.580309477\end{array}$

